Article

\title{
Antimicrobial Activity of Pyrazinamide Coordination Frameworks Synthesized by Mechanochemistry
}

\author{
Sílvia Quaresma ${ }^{1}$, Paula C. Alves ${ }^{1,2}$, Patrícia Rijo ${ }^{3,4} \mathbb{C}$, M. Teresa Duarte ${ }^{1,5, * \mathbb{C}}$ and Vânia André ${ }^{1,2, *(\mathbb{D})}$ \\ 1 Centro de Química Estrutural, Instituto Superior Técnico, Universidade de Lisboa, Av. Rovisco Pais, \\ 1049-001 Lisboa, Portugal; quaresma.silvia@gmail.com (S.Q.); \\ paula.alves.marques@tecnico.ulisboa.pt (P.C.A.) \\ 2 Associação do Instituto Superior Técnico para a Investigação e Desenvolvimento (IST-ID), Av. Rovisco Pais, \\ 1049-003 Lisboa, Portugal \\ 3 Centro de Investigação em Biociências e Tecnologias da Saúde (CBIOS), Universidade Lusófona de \\ Humanidades e Tecnologias, Campo Grande 376, 1749-024 Lisboa, Portugal; p1609@ulusofona.pt \\ 4 Research Institute for Medicines (iMed. ULisboa), Faculty of Pharmacy, Universidade de Lisboa (UL), \\ Av. Prof. Gama Pinto, 1649-003 Lisboa, Portugal \\ 5 Departamento de Engenharia Química, Instituto Superior Técnico, Universidade de Lisboa, Av. Rovisco Pais, \\ 1049-001 Lisboa, Portugal \\ * Correspondence: teresa.duarte@tecnico.ulisboa.pt (M.T.D.); vaniandre@tecnico.ulisboa.pt (V.A.)
}

Citation: Quaresma, S.; Alves, P.C.; Rijo, P.; Duarte, M.T.; André, V.

Antimicrobial Activity of

Pyrazinamide Coordination

Frameworks Synthesized by

Mechanochemistry. Molecules 2021,

26, 1904. https://doi.org/10.3390/

molecules 26071904

Academic Editor: Daniele Castagnolo

Received: 16 February 2021

Accepted: 25 March 2021

Published: 28 March 2021

Publisher's Note: MDPI stays neutral with regard to jurisdictional claims in published maps and institutional affiliations.

Copyright: (c) 2021 by the authors. Licensee MDPI, Basel, Switzerland. This article is an open access article distributed under the terms and conditions of the Creative Commons Attribution (CC BY) license (https:/ / creativecommons.org/licenses/by/ $4.0 /)$.

\begin{abstract}
The urge for the development of a more efficient antibiotic crystalline forms led us to the disclosure of new antibiotic coordination frameworks of pyrazinamide, a well-known drug used for the treatment of tuberculosis, with some of the novel compounds unravelling improved antimycobacterial activity. Mechanochemistry was the preferred synthetic technique to yield novel compounds, allowing the reproduction of a 1D zinc framework, the synthesis of a novel hydrogen bonding manganese framework, and three new compounds with silver. The structural characterization of the novel forms is presented along with stability studies. The increased antimicrobial activity of the new silver-based frameworks against Escherichia coli, Staphylococcus aureus, and Mycobacterium smegmatis is particularly relevant.
\end{abstract}

Keywords: mechanochemistry; supramolecular chemistry; pyrazinamide; antibiotics; antibiotic coordination frameworks

\section{Introduction}

Pyrazinamide (Figure 1) is an antimycobacterial agent, with a well-established function as a front-line drug against tuberculosis that presents the most effective tuberculosis chemotherapy along with isoniazid, rifampicin, and ethambutol [1,2]. Indeed, the use of pyrazinamide in the treatment of tuberculosis [1] is recommend by the World Health Organization (WHO) [3] and it is in the WHO Model List of Essential Medicines [4].<smiles>NC(=O)c1cnccn1</smiles>

Figure 1. Pyrazinamide structure.

Pyrazinamide plays a key role in shortening tuberculosis treatment from 9-12 months to 6 months. This capability seems to be correlated with its ability to kill a special bacterial 
population with low metabolic activity, which resides in acidic $\mathrm{pH}$ environments that are not killed by other tuberculosis drugs, and also its ability to kill persisting Mycobacterium tuberculosis during the initial intensive phase $[1,2,5]$. Despite its remarkable in vivo activity, pyrazinamide is not active against $M$. tuberculosis under usual culture conditions, at approximately neutral $\mathrm{pH}[1,5]$. This discrepancy between the in vivo and in vitro activity of pyrazinamide reflects possible differences between in vivo and in vitro conditions that affect the drug activity. Even though it might not completely explain this discrepancy, it was found that pyrazinamide is active against $M$. tuberculosis only at acidic $\mathrm{pH}$ values [2,5].

A possible strategy to increase the efficiency of commercially available drugs is through the preparation of metal-organic frameworks (MOFs) for pharmaceutical purposes. MOFs are structures based on supramolecular chemistry principles [6,7] that can exhibit some of the highest porosities known, and, therefore, are suitable for diverse applications, including gas storage, luminescence, separation, catalysis, drug delivery [6,8-13], cancer therapy $[14,15]$, and applications in imaging and sensing for therapeutic and diagnostic [12,16-19]. MOFs with biocompatible composition were reported to be viable drug carriers to overcome some of the problems related to drug delivery [9,20-22]. In particular, MOFs designed using antibiotics as ligands to yield antibiotic coordination frameworks (ACFs) were proposed to improve the antimicrobial activity [23-25], as well as the physicochemical properties of the antibiotics [26-33].

Accordingly, the development of new pyrazinamide coordination frameworks recurring to biocompatible metals envisaging synergistic effects can be explored as a viable pathway for the improvement of its antimycobacterial properties. A systematic analysis in the Cambridge Structural Database (CSD) [34] retrieved 48 pyrazinamide-based coordination compounds. Nevertheless, from this universe, the evaluation of the biological activity was studied only for a few compounds, which enclose $\mathrm{Mn}$ (II) and dicyanamide as the second ligand [35]; complexes of $\mathrm{Cu}(\mathrm{II}), \mathrm{Fe}(\mathrm{II}), \mathrm{Co}(\mathrm{II}), \mathrm{Mn}(\mathrm{II})$, and $\mathrm{Ni}(\mathrm{II})$ [36], and of $\mathrm{Au}(\mathrm{I})$ and $\mathrm{Au}(\mathrm{III})$ [37]. Some of these compounds were demonstrated to be more effective against $M$. tuberculosis than the free pyrazinamide, proving the potential of these systems for the improvement of the antimycobacterial properties of pyrazinamide.

Even though MOFs and coordination complexes were traditionally obtained by solution techniques, including hydrothermal and solvothermal synthesis, there is a growing concern regarding the development of new and more sustainable synthetic alternatives. Mechanochemistry is one of these techniques that emerged in many areas, including in the synthesis of MOFs and metal complexes [38,39]. This is an environment-friendly technique that dismisses the use of solvent (neat grinding, NG) [40] or uses minimal amounts of solvent (liquid-assisted grinding, ion-, and liquid-assisted grinding, polymer-assisted grinding-LAG, ILAG, and POLAG, respectively) [41-44]. Besides the evident environmental benefits, this technique also demonstrated advantages concerning other important aspects, such as reaction time and efficiency. From the pharmaceutical perspective, it is important to mention that ball-milling, one of the possible mechanochemical approaches, is listed as a pharmaceutical particle technology to improve the solubility of poorly soluble drugs by reducing their particle size $[28,39,45,46]$.

Herein, we disclose the mechanochemical synthesis and characterization of novel coordination and hydrogen bonding frameworks using pyrazinamide as a linker and biocompatible metals. In this study, besides Escherichia coli and Staphylococcus aureus, we used Mycobacterium smegmatis, a non-pathogenic model organism of $M$. tuberculosis [47], as a first approach to test new therapeutic compounds against tuberculosis [48]. The antibacterial activity assays revealed that, in some cases, these systems showed enhanced activity as compared to the free antibiotic.

\section{Results and Discussion}

Different biocompatible metallic ions (Zn(II), Mn(II) and $\mathrm{Ag}(\mathrm{I})$ ) were tested in an attempt to synthesize coordination frameworks of pyrazinamide (PYR), recurring to mechanochemistry (Scheme 1). The herein called compound 1, $\left.\mathrm{Zn}(\mathrm{PYR})_{2}\left(\mathrm{H}_{2} \mathrm{O}\right)\right]\left(\mathrm{NO}_{3}\right)_{2}$, 
was already obtained from solution techniques (CSD refcode: HAYKUP) [34,49], but it was now reproduced using neat grinding. The discussion of its crystal structure is also included herein for comparison reasons. New compounds were attained with manganese ([Mn(PYR $\left.\left.)_{2}\left(\mathrm{H}_{2} \mathrm{O}\right)_{2}\left(\mathrm{NO}_{3}\right)\right]\left(\mathrm{NO}_{3}\right), 2\right)$ and silver nitrates $\left(\left[\mathrm{Ag}(\mathrm{PYR})_{2}\right]\left(\mathrm{NO}_{3}\right), 3\right)$ and $\left(\left[\mathrm{Ag}(\mathrm{PYR})_{2}\left(\mathrm{NO}_{3}\right)\right], 4\right)$, using a (2:1) reaction stoichiometry. When using a (1:1) stoichiometric ratio with silver nitrate, a different novel compound, 5, was obtained. Structural elucidation by powder and single-crystal X-ray diffraction data, as well as their physicochemical characterization, is presented and discussed, except for 4, which is only structurally characterized, and 5 whose structural determination was precluded as no single crystals where it was possible to obtain. Antimicrobial assays were also performed to assess their antimicrobial activity, except for 4 .

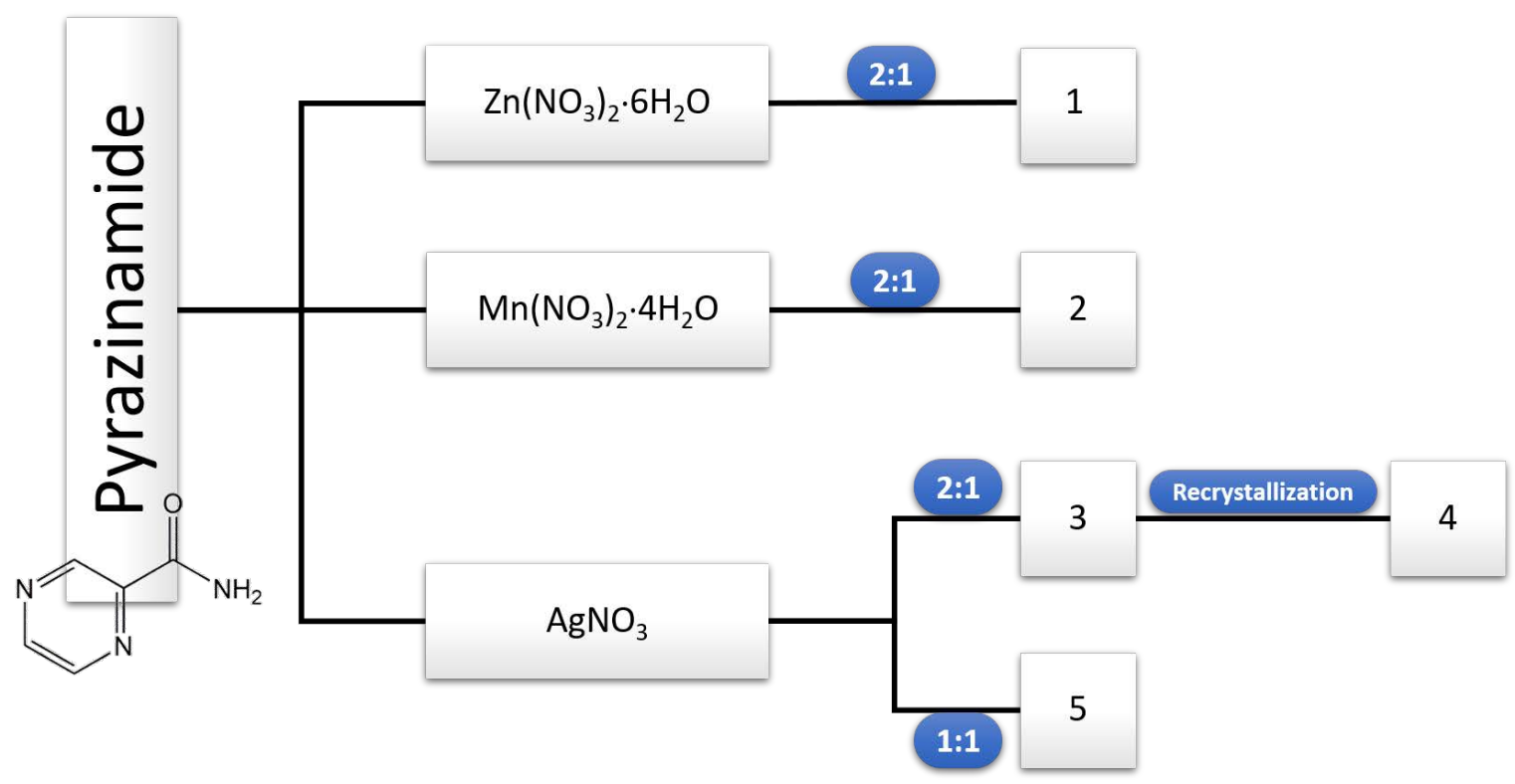

Scheme 1. Summary of the neat grinding reaction conditions, depicting the stoichiometric ratios of pyrazinamide:metal salt used for the synthesis of compounds 1-3, and 5; 4 was obtained by the recrystallization of 3 .

\subsection{Structural Characterization}

The neat grinding reaction of pyrazinamide with zinc nitrate led to the formation of $\left[\mathrm{Zn}(\mathrm{PYR})_{2}\left(\mathrm{H}_{2} \mathrm{O}\right)\right]\left(\mathrm{NO}_{3}\right)_{2}$, compound $\mathbf{1}$. The comparison between the experimental PXRD pattern of 1 with the simulated pattern of HAYKUP (Figure S1) clearly confirmed the reproduction of the form reported previously [34,49]. The asymmetric unit of $\mathbf{1}$ contained one $\mathrm{Zn}$ (II) metal center, two pyrazinamide molecules, one water molecule, and two free nitrate anions. The $\mathrm{Zn}(\mathrm{II})$ metal center was six coordinated by two pyrazinamide ligands, both coordinating via the $\mathrm{N}, \mathrm{O}$-bidentate mode (distances ranging from 2.064(3) to 2.193(5) $\AA)$, but the second ligand further coordinated to a symmetry generated $\left(x, 3 / 2-y,-\frac{1}{2}\right.$ $+\mathrm{z})$ metal center, with a distance of 2.179(5) $\AA$. A water molecule fulfilled the octahedral geometry (2.042(6) $\AA$ ). The equatorial plane was defined by $\mathrm{N}_{4} \mathrm{~N}_{5 \mathrm{c}} \mathrm{N}_{1} \mathrm{O}_{3 \mathrm{~W}}$ atoms, and the oxygen atoms $\mathrm{O}_{1}$ and $\mathrm{O}_{2}$ occupied the apical positions with an axial angle of 172.71(15) ${ }^{\circ}$ $\left(\mathrm{O}_{1}-\mathrm{Zn}_{1}-\mathrm{O}_{2}\right)$ (Figure $2 \mathrm{a}$, b and Table S1).

One of the pyrazinamide ligands bridged the consecutive $\mathrm{Zn}$ (II) metal centers, promoting the formation of a 1D framework with zig-zag chains aligning along the $\mathrm{c}$ axis. The other crystallographically independent pyrazinamide coordinated to a single $\mathrm{Zn}$ (II) center, precluding the formation of 2D frameworks (Figure 3). 
a)

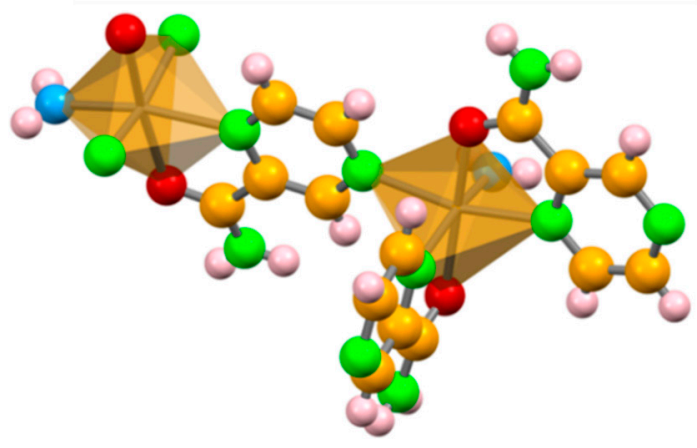

b)

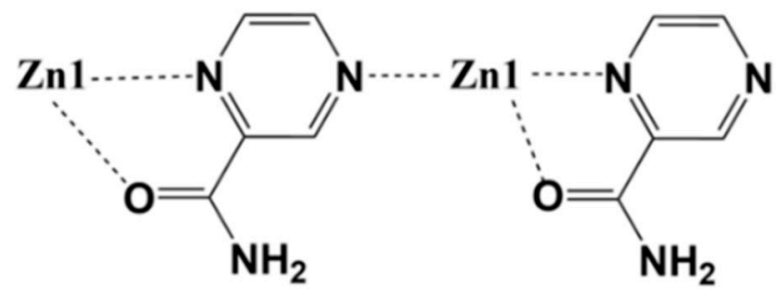

Figure 2. (a) View of the molecular structure of 1, evidencing the coordination environment; (b) details on pyrazinamide coordination modes. Nitrate anions were omitted for clarity. Color code: $\mathrm{C}$, yellow; O, red; Ow, cyan; N, green; H, white; and octahedral polyhedral representation, pale yellow.

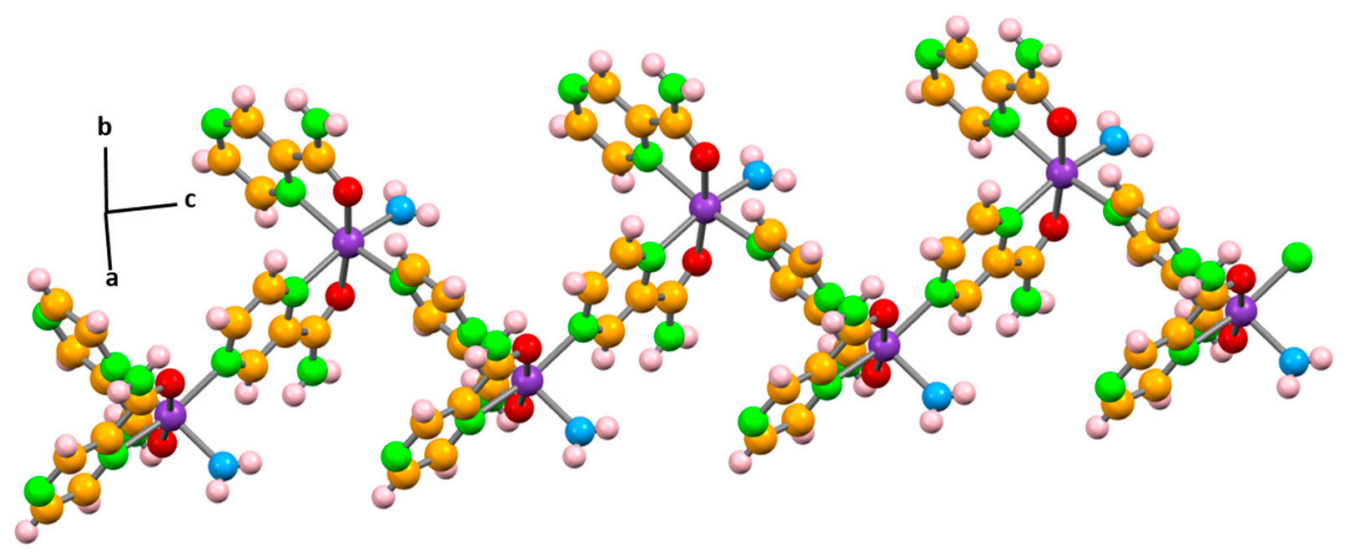

Figure 3. Representation of the 1D frameworks of 1, extending along the c axis. Color code: $\mathrm{Zn}(\mathrm{II})$, purple C, yellow; O, red; Ow, cyan; N, green; and $\mathrm{H}$, white.

The overall supramolecular arrangement of $\mathbf{1}$ was based on hydrogen bond interactions established amongst the two free nitrate anions and the coordinated water molecule (Table 1). The water molecule interacted as a donor with both free nitrates via $\mathrm{O}_{3 \mathrm{~W}^{-}}$ $\mathrm{H}_{11 \mathrm{~W}} \cdots \mathrm{O}_{4}(2.810(8) \AA)$ and $\mathrm{O}_{3 \mathrm{~W}}-\mathrm{H}_{12 \mathrm{~W}} \cdots \mathrm{O}_{8}(2.810(8) \AA)$ hydrogen bonds, and as an acceptor from the amide $\mathrm{NH}_{2}$ fragment of pyrazinamide $\mathrm{N}, \mathrm{O}$-chelated through the $\mathrm{N}_{3}-$ $\mathrm{H}_{7} \cdots \mathrm{O}_{3 \mathrm{~W}}(3.193(8) \AA)$ hydrogen bond. This later amide $\mathrm{NH}_{2}$ fragment also established hydrogen bonds with the two free nitrates- $\mathrm{N}_{3}-\mathrm{H}_{7} \cdots \mathrm{O}_{5}(3.163(8) \AA)$ and $\mathrm{N}_{3}-\mathrm{H}_{8} \cdots \mathrm{O}_{7}$ (2.937(8) $\AA$ ). The crystal packing was further complemented by interactions between the amide $\mathrm{NH}_{2}$ fragment of the pyrazinamide that bridged the $\mathrm{Zn}(\mathrm{II})$ metal centers and a free nitrate anion $\left(\mathrm{N}_{6}-\mathrm{H}_{9} \cdots \mathrm{O}_{5}(3.231(8) \AA)\right.$ and $\mathrm{N}_{6}-\mathrm{H}_{10} \cdots \mathrm{O}_{4}(2.913(7) \AA)$ ), generating a 3D hydrogen bond framework (Figure $4 \mathrm{a}, \mathrm{b}$ and Table 1 ).

Compound 2 was also prepared by the neat grinding pyrazinamide with manganese nitrate. The structure was determined from single crystal X-ray diffraction (SCXRD) data and formulated as $\left[\mathrm{Mn}(\mathrm{PYR})_{2}\left(\mathrm{H}_{2} \mathrm{O}\right)_{2}\left(\mathrm{NO}_{3}\right)\right] \mathrm{NO}_{3}$. PXRD data proved that the compound was obtained as a pure phase (Figure S2). The asymmetric unit of $\mathbf{2}$ was based on one $\mathrm{Mn}$ (II) metal center, two pyrazinamide molecules, two coordinated water molecules, one coordinate nitrate, and one free nitrate. Similarly to what was described for $\mathbf{1}$, in compound $\mathbf{2}$, the crystallographically independent pyrazinamide molecules showed different coordination behaviors, as one was chelated by the $\mathrm{N}, \mathrm{O}$-bidentate mode (distances of 2.3433(12) and 2.1570(1) $\AA$, respectively), and the other only bound to the metal by the pyrazine-N atom $(2.3508(12) \AA)$. The Mn(II) coordination sphere was further completed by one nitrate (2.3161(13) $\mathrm{A}$ ) and two water molecules (2.1178(14) and 2.1640(13) $\AA$ ). Mn(II) assumed a 
slightly compressed octahedral geometry, with the equatorial plane being defined by the $\mathrm{O}_{1} \mathrm{~N}_{4} \mathrm{O}_{3} \mathrm{~N}_{1}$ atoms, and the water molecules occupying the apical positions with an axial angle of $169.75(5)^{\circ}\left(\mathrm{O}_{1 \mathrm{~W}}-\mathrm{Mn}_{1}-\mathrm{O}_{2 \mathrm{~W}}\right)$ (Figure $5 \mathrm{a}$,b and Table S2).

Table 1. List of the main hydrogen bonds found for compounds 1-4.

\begin{tabular}{|c|c|c|c|c|c|c|}
\hline Compound & Symmetry Operation & $\mathbf{D}-\mathbf{H} \cdots \mathbf{A}$ & $\begin{array}{c}d(\mathrm{D}-\mathrm{H}) \\
(\AA)\end{array}$ & $\begin{array}{c}d(\mathrm{H} \cdots \mathrm{A}) \\
(\AA)\end{array}$ & $\begin{array}{c}d(\mathrm{D} \cdots \mathrm{A}) \\
(\AA)\end{array}$ & $\begin{array}{c}\text { (DHA) } \\
\left({ }^{\circ}\right)\end{array}$ \\
\hline \multirow{7}{*}{1} & $1-x, 1-y, 1-z$ & $\mathrm{~N}_{3}-\mathrm{H}_{7} \cdots \mathrm{O}_{3 \mathrm{~W}}$ & 0.86 & 2.50 & $3.193(8)$ & 138 \\
\hline & $1-x, 1-y, 1-z$ & $\mathrm{~N}_{3}-\mathrm{H}_{7} \cdots \mathrm{O}_{5}$ & 0.86 & 2.42 & $3.163(8)$ & 144 \\
\hline & $x, y, z$ & $\mathrm{~N}_{3}-\mathrm{H}_{8} \cdots \mathrm{O}_{7}$ & 0.86 & 2.08 & $2.937(8)$ & 172 \\
\hline & $2-x, 1-y, 1-z$ & $\mathrm{~N}_{6}-\mathrm{H}_{9} \cdots \mathrm{O}_{5}$ & 0.86 & 2.41 & $3.231(8)$ & 161 \\
\hline & $2-x, \frac{1}{2}+y, \frac{1}{2}-z$ & $\mathrm{~N}_{6}-\mathrm{H}_{10} \cdots \mathrm{O}_{4}$ & 0.86 & 2.07 & $2.913(7)$ & 166 \\
\hline & $x, y, z$ & $\mathrm{O}_{3 \mathrm{~W}}-\mathrm{H}_{11 \mathrm{~W}} \cdots \mathrm{O}_{4}$ & $0.75(6)$ & $2.06(7)$ & $2.781(8)$ & $162(9)$ \\
\hline & $1-x, 1-y, 1-z$ & $\mathrm{O}_{3 \mathrm{~W}}-\mathrm{H}_{12 \mathrm{~W}} \cdots \mathrm{O}_{8}$ & $0.76(7)$ & $2.05(7)$ & $2.810(8)$ & 177(7) \\
\hline \multirow{10}{*}{2} & $1-x, 2-y,-z$ & $\mathrm{~N}_{3}-\mathrm{H}_{1 \mathrm{~N}} \cdots \mathrm{O}_{8}$ & $0.77(2)$ & $2.15(3)$ & $2.889(2)$ & $159(2)$ \\
\hline & $2-x, 1-y, 1-z$ & $\mathrm{O}_{1 \mathrm{w}}-\mathrm{H}_{1 \mathrm{w}} \cdots \mathrm{O}_{2}$ & $0.86(3)$ & $1.94(3)$ & $2.7773(18)$ & $166(2)$ \\
\hline & $x, 1+y, z$ & $\mathrm{~N}_{3}-\mathrm{H}_{2 \mathrm{~N}} \cdots \mathrm{O}_{4}$ & $0.89(3)$ & $2.54(2)$ & $3.368(2)$ & $155(2)$ \\
\hline & $x, 1+y, z$ & $\mathrm{~N}_{3}-\mathrm{H}_{2 \mathrm{~N}} \cdots \mathrm{O}_{5}$ & $0.89(3)$ & $2.41(3)$ & $3.228(2)$ & $153(2)$ \\
\hline & $x, y, z$ & $\mathrm{O}_{1 \mathrm{w}}-\mathrm{H}_{2 \mathrm{w}} \cdots \mathrm{O}_{6}$ & $0.81(3)$ & $1.87(3)$ & $2.6723(19)$ & $169(3)$ \\
\hline & $1+x, y, 1+z$ & $\mathrm{~N}_{6}-\mathrm{H}_{3 \mathrm{~N}} \cdots \mathrm{N}_{2}$ & $0.81(3)$ & $2.23(2)$ & $3.008(2)$ & $163(2)$ \\
\hline & $1-x, 1-y, 1-z$ & $\mathrm{O}_{2 \mathrm{w}}-\mathrm{H}_{3 \mathrm{w}} \cdots \mathrm{O}_{3}$ & $0.75(3)$ & $2.28(3)$ & $2.9714(18)$ & $155(3)$ \\
\hline & $1-x, 1-y, 1-z$ & $\mathrm{O}_{2 \mathrm{w}}-\mathrm{H}_{3 \mathrm{w}} \cdots \mathrm{O}_{4}$ & $0.75(3)$ & $2.51(3)$ & $3.186(2)$ & $150(3)$ \\
\hline & $2-x, 2-y, 1-z$ & $\mathrm{~N}_{6}-\mathrm{H}_{4 \mathrm{~N}} \cdots \mathrm{O}_{7}$ & $0.87(3)$ & $2.20(3)$ & $2.880(2)$ & $135(2)$ \\
\hline & $1-x, 1-y, 1-z$ & $\mathrm{O}_{2 \mathrm{w}}-\mathrm{H}_{4 \mathrm{w}} \cdots \mathrm{O}_{2}$ & $0.89(3)$ & $1.84(3)$ & $2.7278(17)$ & $178(3)$ \\
\hline \multirow{3}{*}{3} & $x, y, z$ & $\mathrm{~N}_{3}-\mathrm{H}_{1 \mathrm{~N}} \cdots \mathrm{N}_{2}$ & $0.90(5)$ & $2.44(8)$ & $2.733(7)$ & $100(6)$ \\
\hline & $2-x 1-y, 1-z$ & $\mathrm{~N}_{3}-\mathrm{H}_{1 \mathrm{~N}} \cdots \mathrm{N}_{2}$ & $0.90(5)$ & $2.44(8)$ & $3.150(7)$ & $137(6)$ \\
\hline & $1-x, 1-y, 2-z$ & $\mathrm{~N}_{3}-\mathrm{H}_{2 \mathrm{~N}} \cdots \mathrm{O}_{1}$ & $0.90(6)$ & $2.02(6)$ & $2.888(7)$ & $164(6)$ \\
\hline \multirow{2}{*}{4} & $x,-y, 1-z$ & $\mathrm{~N}_{3}-\mathrm{H}_{1 \mathrm{~N}} \cdots \mathrm{N}_{2}$ & $0.81(8)$ & $2.48(8)$ & $3.118(8)$ & $136(7)$ \\
\hline & $2-x, 1-y, 1-z$ & $\mathrm{~N}_{3}-\mathrm{H}_{2 \mathrm{~N}} \cdots \mathrm{O}_{1}$ & $0.79(8)$ & $2.10(8)$ & $2.883(8)$ & $177(8)$ \\
\hline
\end{tabular}

a)

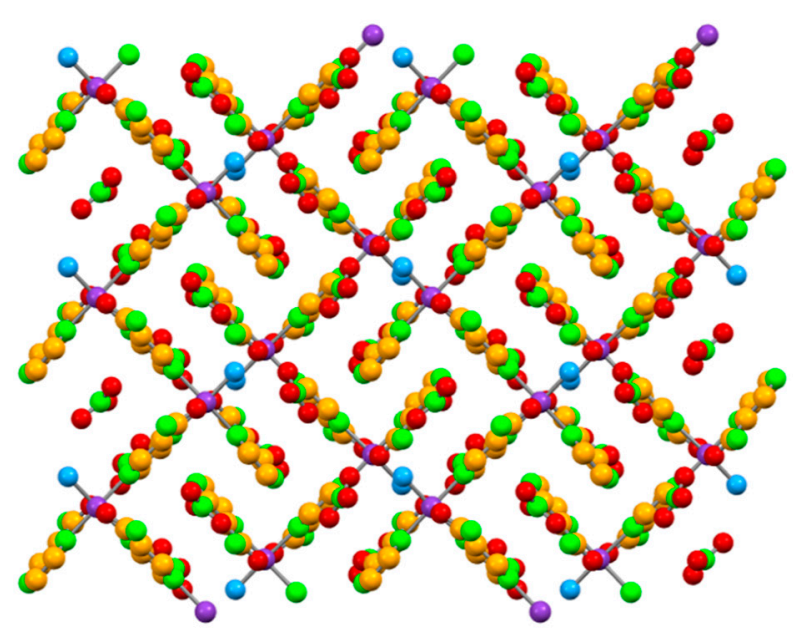

b)

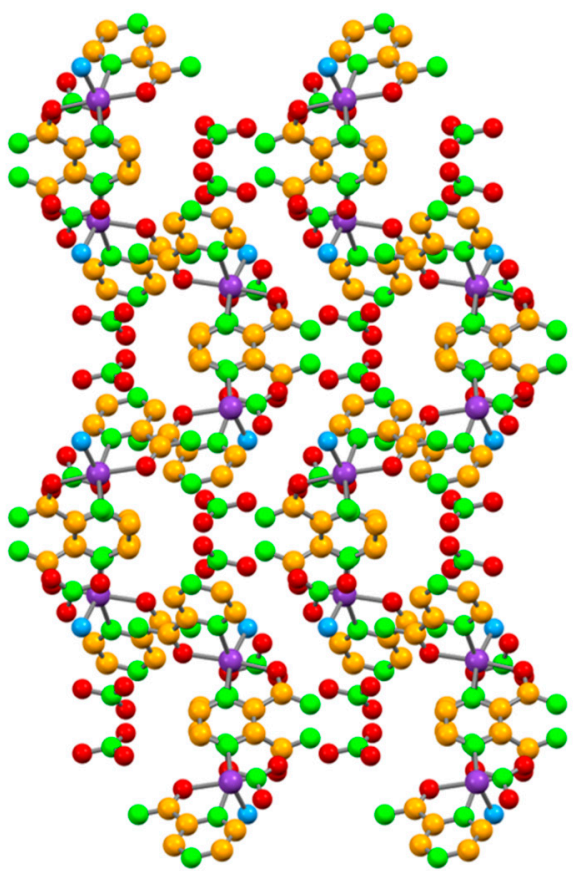

Figure 4. Supramolecular arrangement of $\mathbf{1}$ in a view along the (a) a axis and (b) the c axis. $\mathrm{H}$ atoms were omitted for clarity. Color code: $\mathrm{Zn} 2+$, purple; $\mathrm{C}$, yellow; $\mathrm{O}$, red; Ow, cyan; $\mathrm{N}$, green; and $\mathrm{H}$, white. 
a)

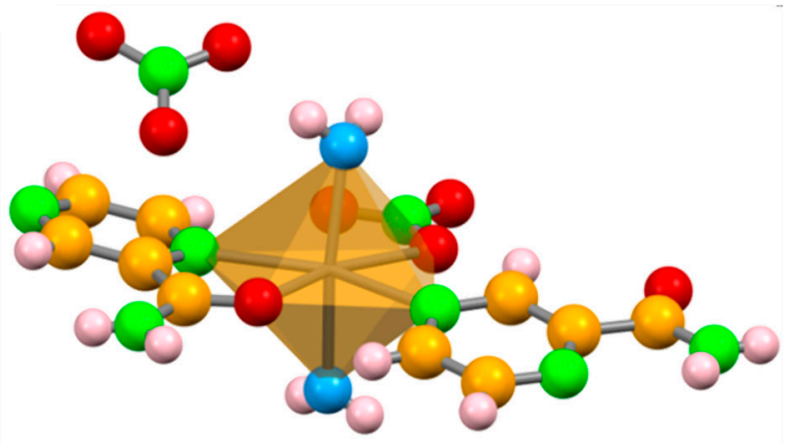

b)<smiles></smiles>

Figure 5. (a) View of the molecular structure of 2. (b) Details on pyrazinamide coordination modes. Nitrate anions were omitted for clarity. Color code: $\mathrm{C}$, yellow; $\mathrm{O}$, red; Ow, cyan; N, green; $\mathrm{H}$, white; and octahedral polyhedral representation, pale yellow.

Despite the different coordination behavior of the pyrazinamide molecules in 2, there was no bridging of the consecutive metal centers, and therefore, this was a $0 \mathrm{D}$ structure. Its supramolecular arrangement could be described as hydrogen bonded chains extending both along the $b$ axis and the [101] direction. The chains formed along $\mathrm{b}$ were attained through hydrogen bonds established between the $\mathrm{NH}_{2}$ group of the pyrazinamide molecule $\mathrm{N}, \mathrm{O}$-chelated, and the coordinated nitrate ion with the nitrogen atom $\mathrm{N}_{3}$ making bifurcated hydrogen bonds with both oxygen atoms of the coordinated nitrate: $\mathrm{N}_{3}-\mathrm{H}_{2 \mathrm{~N}} \cdots \mathrm{O}_{4}(3.368(2)$ $\AA)$, and $\mathrm{N}_{3}-\mathrm{H}_{2 \mathrm{~N}} \cdots \mathrm{O}_{5}(3.228(2) \AA)$. The chains growing along [101] were based on $\mathrm{N}_{6}$ $\mathrm{H}_{3 \mathrm{~N}} \cdots \mathrm{N}_{2}(3.008(2) \AA)$ hydrogen bonds established between the amide $\mathrm{NH}_{2}$ fragment of the $\mathrm{N}, \mathrm{O}$-chelated pyrazinamide and the pyrazine- $\mathrm{N}$ atom of consecutive crystallographically independent pyrazinamide molecules. This network was further reinforced by hydrogen bonds established between the $\mathrm{NH}_{2}$ group and the free nitrate, $\mathrm{N}_{6}-\mathrm{H}_{4 \mathrm{~N}} \cdots \mathrm{O}_{7}(2.880(2) \AA)$ and $\mathrm{N}_{3}-\mathrm{H}_{1 \mathrm{~N}} \cdots \mathrm{O}_{8}(2.889(2) \AA ̊$ ) (Figure 6, Table 1).

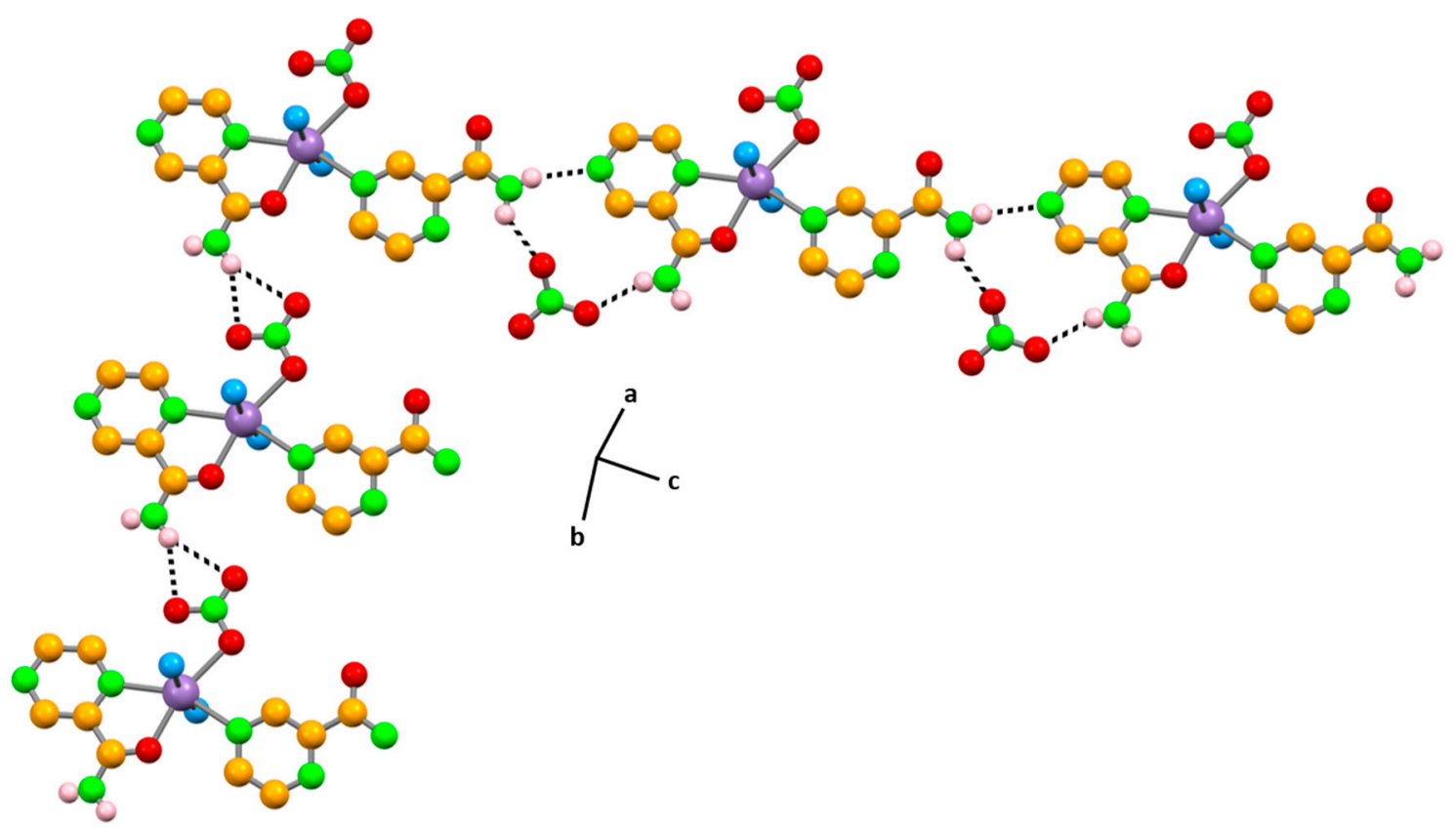

Figure 6. Representation of the hydrogen bonding frameworks of 2 extending along the b axis and the [101] direction, depicting the hydrogen bonds established in each layer. $\mathrm{H}$ atoms not involved in the hydrogen bonds were omitted for clarity. Color code: $\mathrm{Mn}(\mathrm{II})$, purple; $\mathrm{C}$, yellow; $\mathrm{O}$, red; Ow, cyan; $\mathrm{N}$, green; and $\mathrm{H}$, white. 
Both water molecules interacted with the pyrazinamide amide $\mathrm{O}$ atom via $\mathrm{O}_{1 \mathrm{~W}^{-}}$ $\mathrm{H}_{1 \mathrm{~W}} \cdots \mathrm{O}_{2}(2.7773(18) \AA)$ and $\mathrm{O}_{2 \mathrm{~W}}-\mathrm{H}_{4 \mathrm{~W}} \cdots \mathrm{O}_{2}(2.7278(17) \AA)$. One of the water molecules further established hydrogen bonds with two oxygen atoms of the coordinated nitrate $\left(\mathrm{O}_{2 \mathrm{~W}}-\mathrm{H}_{3 \mathrm{~W}} \cdots \mathrm{O}_{3}\left(2.9714(18) \AA\right.\right.$ and $\mathrm{O}_{2 \mathrm{~W}}-\mathrm{H}_{3 \mathrm{~W}} \cdots \mathrm{O}_{4}$ (3.186(2) $\AA$ ), while the other water molecule interacted with the free nitrate anion $\left(\mathrm{O}_{1 \mathrm{~W}}-\mathrm{H}_{2 \mathrm{~W}} \cdots \mathrm{O}_{6}(2.6723(19) \AA)\right.$ (Figure 7a). In the overall supramolecular arrangement, parallel layers of the complex aligned along the [101] plane, with the water molecules lying in between the layers (Figure 7b).

a)

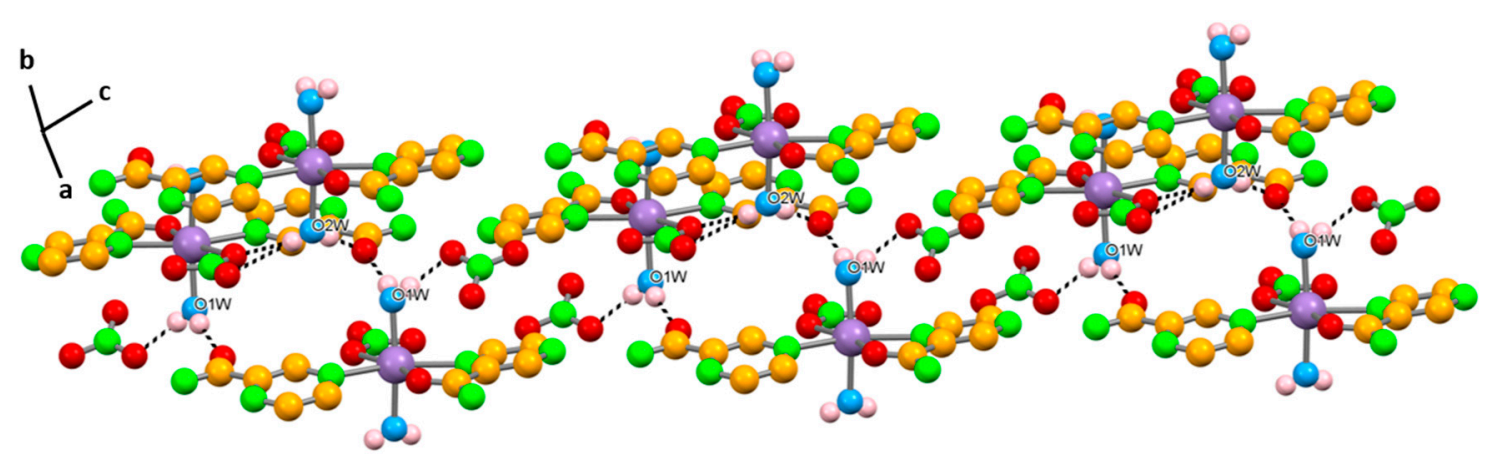

b)

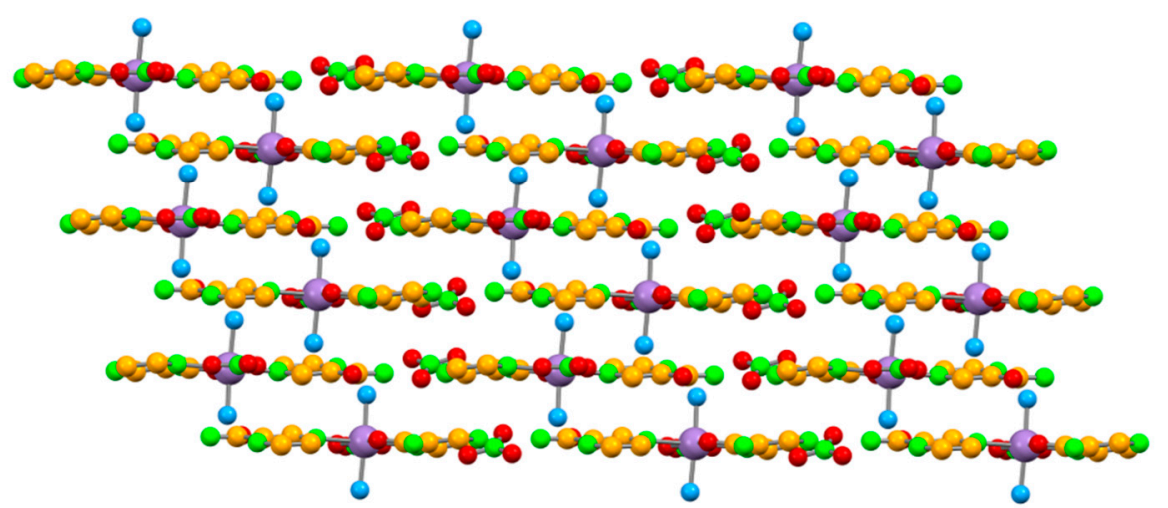

Figure 7. (a) Representation of parallel layers of 2 with the hydrogen bonds established between them. (b) Supramolecular arrangement of $\mathbf{2}$ in a view along b. For clarity, $\mathrm{H}$ atoms not involved in hydrogen bonds were omitted in (a); all $\mathrm{H}$ atoms were omitted in (b). Color code: Mn(II), purple; C, yellow; OPYR, red; Ow, cyan; N, green; H, white; and OH2O, blue.

Comparison of the FTIR spectra of pyrazinamide and 2 confirmed the presence of the coordinated water molecules, as the $v(\mathrm{O}-\mathrm{H})$ stretch at $\sim 3250 \mathrm{~cm}^{-1}$ was observed. The shift from 1704 to $1673 \mathrm{~cm}^{-1}$ of the carbonyl band confirmed that the carbonyl group participates in the coordination to $\mathrm{Mn}(\mathrm{II})$. In addition, the $v_{\mathrm{asym}}\left(\mathrm{NO}_{3}{ }^{-}\right)$and $v_{\mathrm{sym}}\left(\mathrm{NO}_{3}{ }^{-}\right)$stretching vibrations centered at ca. 1329 and $814 \mathrm{~cm}^{-1}$ ascertained the presence of the coordinated nitrate (Figure 8).

Using silver nitrate as the starting material, it was possible to attain three different reaction products $-3,4$, and 5 . Both 3 and 5 were obtained by neat grinding for $15 \mathrm{~min}-3$ was achieved starting from a (2:1) ratio, while 5 was achieved with a (1:1) ratio. In the recrystallization attempts to yield good quality single crystals of 3 , compound 4 was also identified. The structures of 3 and $\mathbf{4}$ were disclosed by SCXRD data and formulated as $\left[\mathrm{Ag}(\mathrm{PYR})_{2}\right]\left(\mathrm{NO}_{3}\right)$ and $\left[\mathrm{Ag}(\mathrm{PYR})_{2}\left(\mathrm{NO}_{3}\right)\right]$, respectively. PXRD proved that compound 3 was prepared as a pure phase (Figure S3). Due to the low amount of crystals of 4 in the recrystallization bulk, only its structural characterization was presented herein. However, we could show 4 that was a novel compound through a comparison of the experimental PXRD patterns of 3 and 4 (Figure S4). 


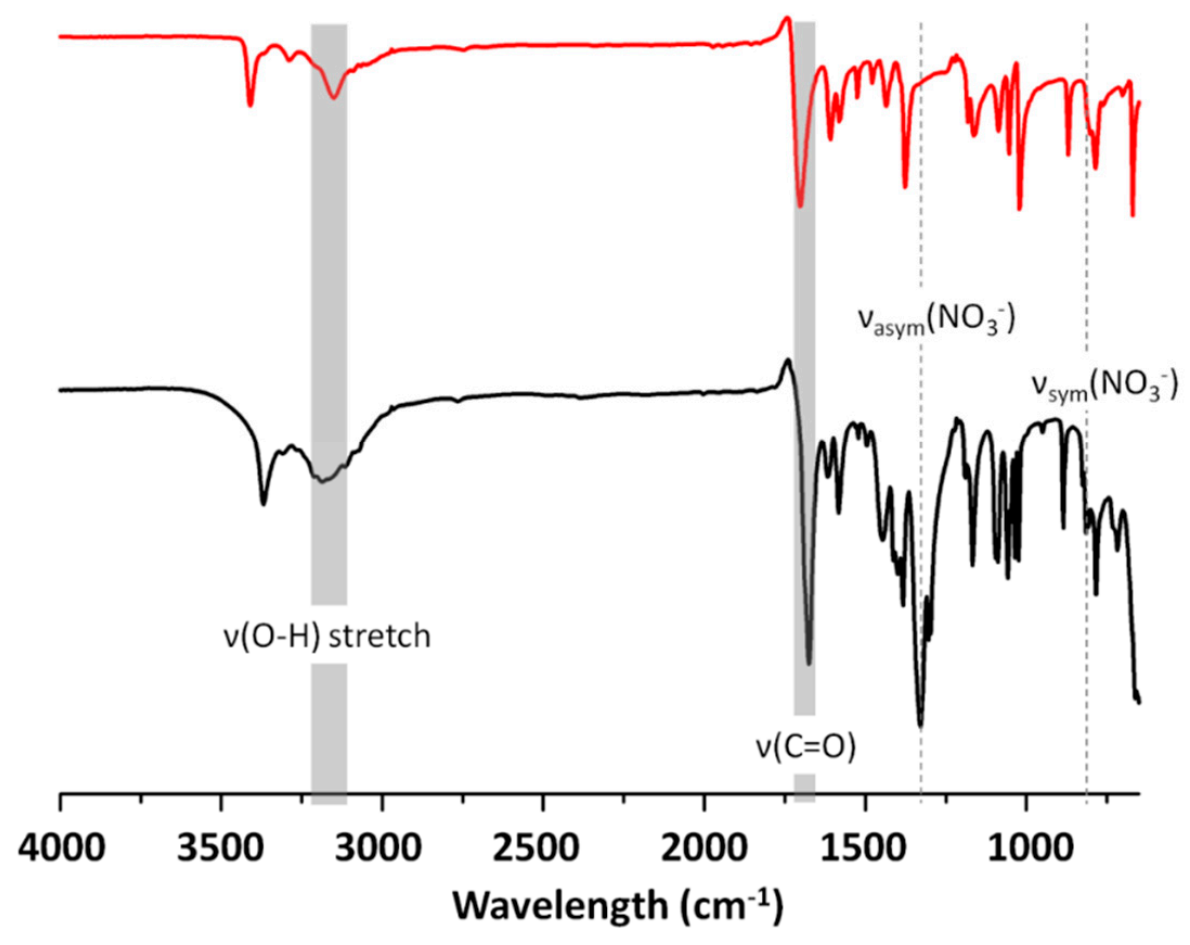

Figure 8. FTIR for pyrazinamide (top) compared with 2 (bottom) (y-axis: transmittance (\%)).

The asymmetric unit of 3 was composed by a half $\mathrm{Ag}(\mathrm{I})$ metal center, one pyrazinamide molecule and half a non-coordinated nitrate. The $\mathrm{Ag}(\mathrm{I})$ metal center assumed a distorted linear geometry (N-Ag-N 154.1(3) ${ }^{\circ}$ ) coordinating to two pyrazinamide ligands by the pyrazine-N atom $(2.230(5) \AA)$ and giving rise to $\left[\mathrm{Ag}(\mathrm{PYR})_{2}\right]^{+}$ions (Figure $9 \mathrm{a}, \mathrm{b}$ and Table S3).

a)

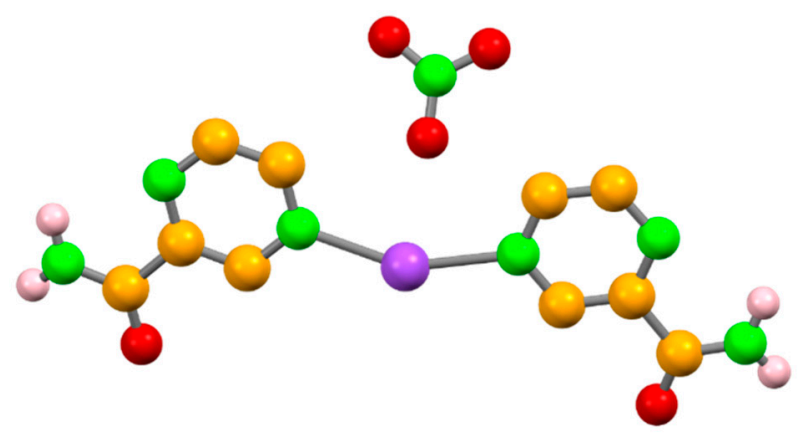

b)<smiles></smiles>

Figure 9. (a) View of the molecular structure of 3. (b) Details on the pyrazinamide coordination mode. Color code: C, yellow; $\mathrm{O}$, red; $\mathrm{N}$, green; $\mathrm{H}$, white; and tetrahedral polyhedral representation, violet.

This type of coordination led to a OD structure, similarly to what was observed in 2. The combination of $R_{2}^{2}(8)$ and $R_{2}^{2}(10)$ synthons generated a $2 \mathrm{D}$ hydrogen bonding framework that characterized the supramolecular arrangement of 3 . While the $R_{2}^{2}(8)$ homosynthons were established between neighboring amide moieties (2.883(8) $\AA$ ), the $R_{2}^{2}(10)$ synthons arose from the interaction between the $\mathrm{N}$-pyrazine and the $\mathrm{NH}_{2}$-amide groups (3.150(7) $\AA$ ). Honeycomb-like layers of $\left[\mathrm{Ag}(\mathrm{PYR})_{2}\right]^{+}$ions were formed approximately within the [202] plane, with the nitrate counterions lying in the cavity of the honeycomb (Figure 10a). No hydrogen bonds were established with the nitrate ions, but each $\mathrm{Ag}(\mathrm{I})$ metal center was involved in short contacts with two nitrates in the same plane and two in neighboring planes (Figure 10b). 
a)

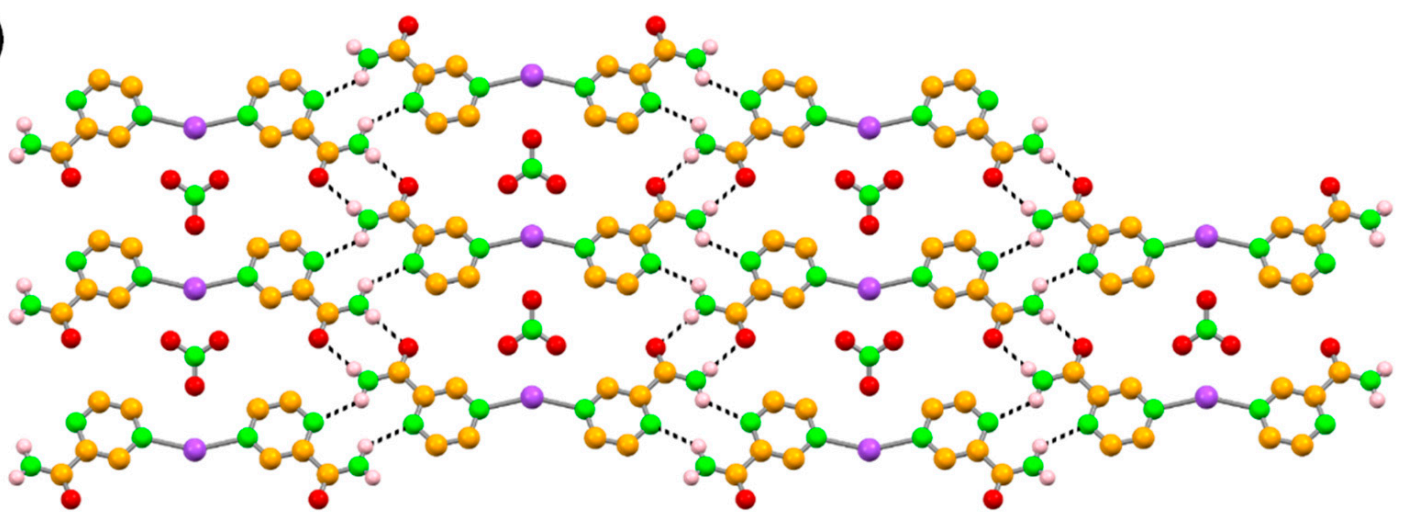

b)

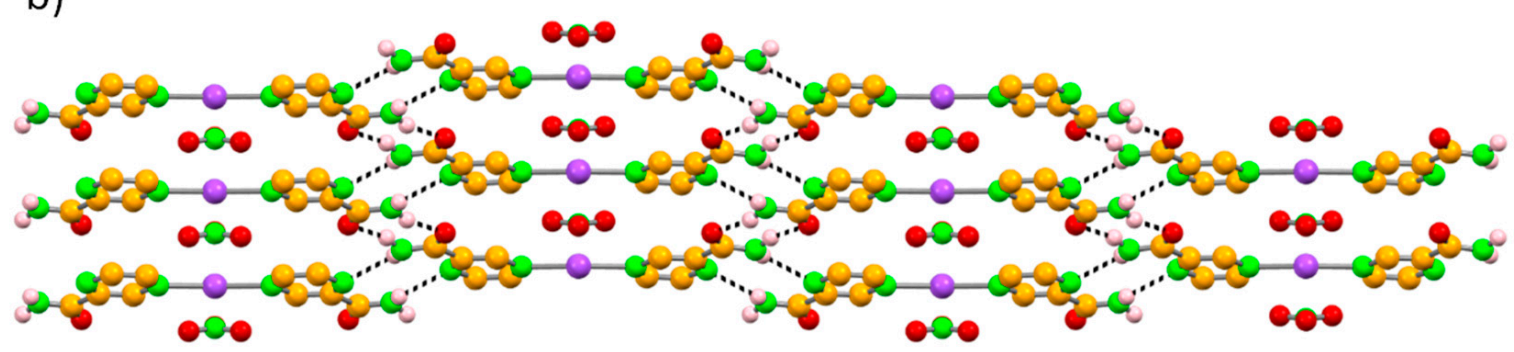

Figure 10. View of the molecular structure of 3 , in a view along the $(\mathbf{a})$ a and $(\mathbf{b}) \mathrm{c}$ axis. Color code: $\mathrm{C}$, yellow; $\mathrm{O}$, red; $\mathrm{N}$, green; $\mathrm{H}$, white; and $\mathrm{Ag}$, violet.

The asymmetric unit of 4 was formed by half $\mathrm{Ag}(\mathrm{I})$ metal center, one pyrazinamide molecule, and half a coordinated nitrate. The coordination of the nitrate precluded the linear geometry observed in 3, and thus, in 4 , the $\mathrm{Ag}(\mathrm{I})$ metal center assumed a distorted tetrahedral geometry, coordinating to two pyrazinamide ligands by the pyrazine- $\mathrm{N}$ atom $(2.227(4) \AA)$ and two nitrates (2.227(4) $\AA$ ) (Figure 11a,b, and Table S4). It is noteworthy that the coordination mode of pyrazinamide was maintained in $\mathbf{3}$ and 4.

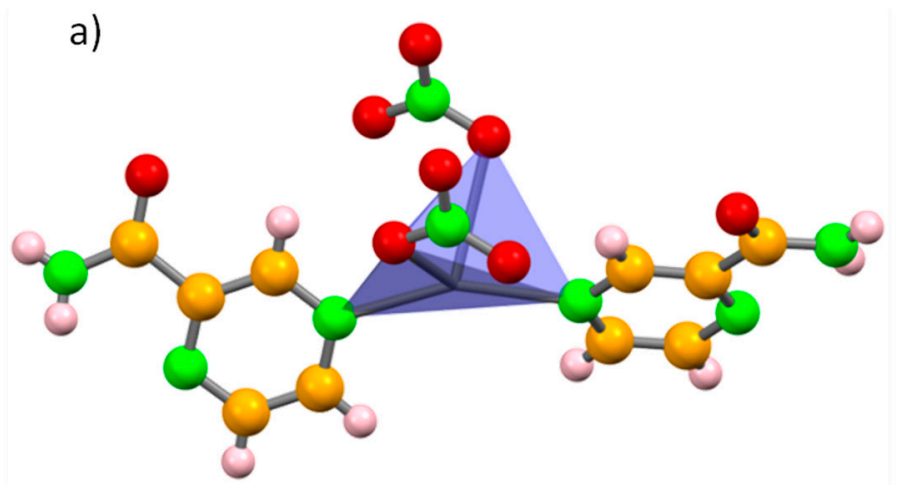

b)<smiles></smiles>

Figure 11. (a) View of the molecular structure of 4, evidencing the coordination environment. (b) Details on the pyrazinamide coordination mode. Color code: $\mathrm{C}$, yellow; $\mathrm{O}$, red; $\mathrm{N}$, green; $\mathrm{H}$, white; and tetrahedral polyhedral representation, violet.

In 4, the nitrate ions connect to the consecutive $\mathrm{Ag}(\mathrm{I})$ centers, giving rise to a $1 \mathrm{D}$ framework that grows along $a$ as chains (Figure 12a). Consecutive parallel chains pack in a head-to-head fashion and interact among them by $\mathrm{N}_{3}-\mathrm{H}_{1 \mathrm{~N}} \cdots \mathrm{N}_{2}(3.118(8) \AA$ ) and $\mathrm{N}_{3}-\mathrm{H}_{2 \mathrm{~N}} \cdots \mathrm{O}_{1}\left(2.883(8) \AA\right.$ ) hydrogen bonds (Figure $12 \mathrm{~b}, \mathrm{c}$ and Table 1 ), giving rise to $R_{2}^{2}(10)$ and $R_{2}^{2}(8)$ synthons, respectively. 
a)

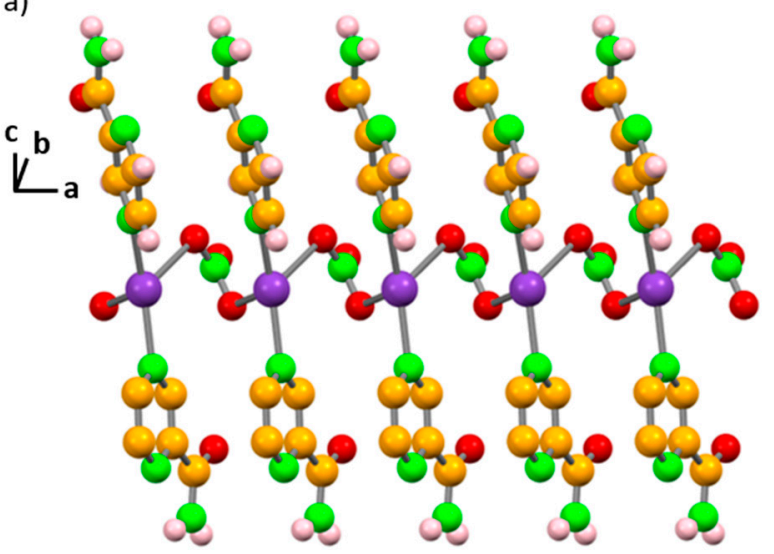

b)

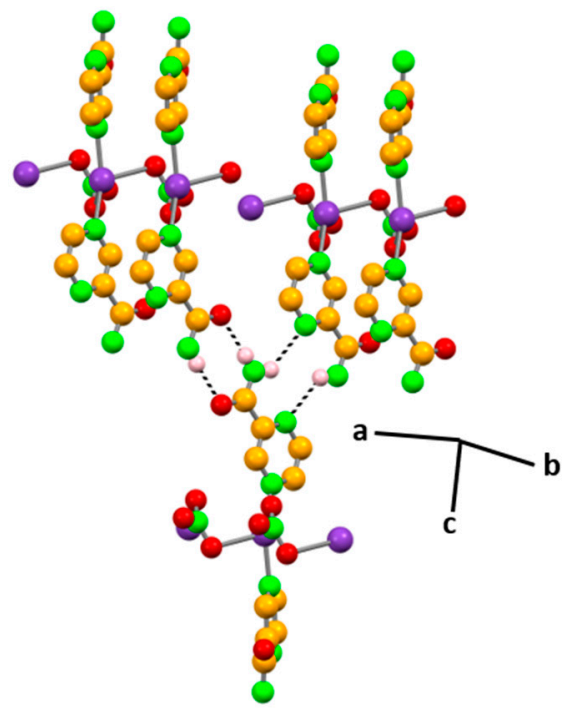

c)

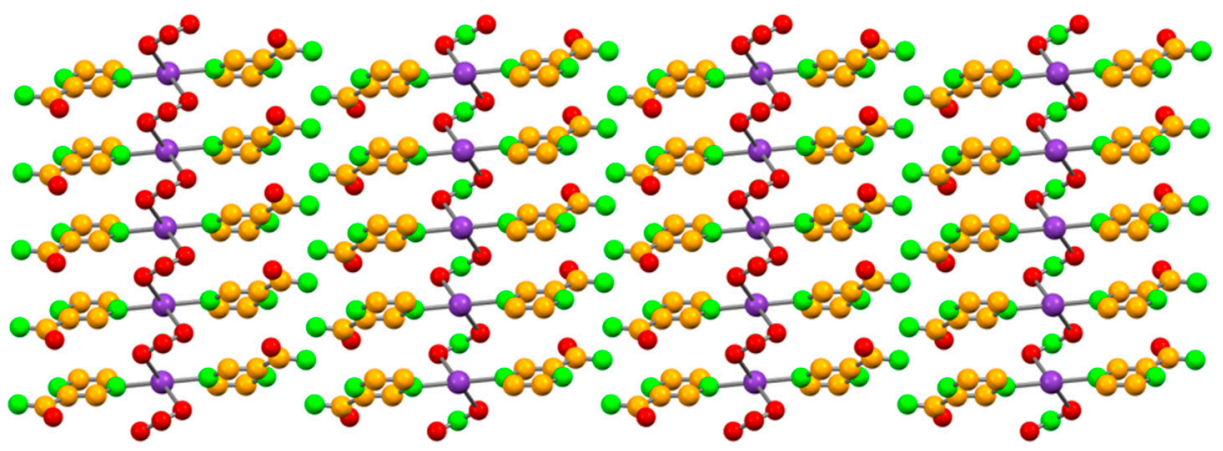

Figure 12. (a) Representation of one $1 \mathrm{D}$ chain of 4 running along a direction. (b) Highlight of the $\mathrm{N}_{3}-\mathrm{H}_{1 \mathrm{~N}} \cdots \mathrm{N}_{2}$ and $\mathrm{N}_{3}-\mathrm{H}_{2 \mathrm{~N}} \cdots \mathrm{O}_{1}$ hydrogen bonds interactions between the chains; (c) supramolecular arrangement of 4 in a view along $\mathrm{b}$. For clarity, $\mathrm{H}$ atoms not involved in hydrogen bonds were omitted in (a) and (b); in (c) all $\mathrm{H}$ atoms were omitted. Color code: $\mathrm{Ag}(\mathrm{I})$ purple; $\mathrm{C}$, yellow; $\mathrm{O}$, red; $\mathrm{N}$, green; and $\mathrm{H}$, white.

The formation of the novel compound 5 was confirmed by PXRD (Figure S5). Unfortunately, despite the many attempts carried out, its structural characterization was not possible.

Regarding the FTIR spectrum of 3, it was possible to confirm that the carbonyl group did not participate in coordination to $\mathrm{Ag}(\mathrm{I})$, with its band being registered at $1704 \mathrm{~cm}^{-1}$ (Figure 13). On the other hand, a small peak was detected at $1704 \mathrm{~cm}^{-1}$ and a more intense peak appeared at $1674 \mathrm{~cm}^{-1}$ in the spectrum of 5 (Figure 13), and therefore this shifted peak might indicate that the coordination via the carbonyl group was a possibility in $\mathbf{5}$, as seen in $\mathbf{1}$ and $\mathbf{2}$.

Hirshfeld surface analysis was used to further understand the intermolecular interactions in compounds 1-4 (Figure 14a and Figures S6-S10). The most representative interactions were indeed the $\mathrm{O} \cdots \mathrm{H} / \mathrm{H} \cdots \mathrm{O}$ contacts with $49.2,46.7,36.9 \%$, and $37.4 \%$, for 1, 2, 3, and 4, respectively, which were represented by the two characteristic wings of hydrogen bonds. The $\mathrm{H} \cdots \mathrm{H}$ intercontacts showed large surfaces in the three structures, corresponding to the second most abundant contacts $(14,19.3,17.9$, and $19.1 \%$ for $\mathbf{1}, \mathbf{2}, \mathbf{3}$, and 4, respectively). The $\mathrm{N} \cdots \mathrm{H} / \mathrm{H} \cdots \mathrm{N}$ interactions corresponded to $9.1,11.5,12.4$, and $11.4 \%$ of the total interactions in $\mathbf{1}, \mathbf{2}, \mathbf{3}$, and $\mathbf{4}$, respectively, and were characterized by two sharp spikes pointing towards the upper and lower left of the plots corresponding to the described hydrogen bonds involving the $\mathrm{N}$ atoms. Besides these major interactions, the $\mathrm{C} \cdots \mathrm{C}, \mathrm{C} \cdots \mathrm{H} / \mathrm{H} \cdots \mathrm{C}, \mathrm{O} \cdots \mathrm{C} / \mathrm{C} \cdots \mathrm{O}$, and $\mathrm{O} \cdots \mathrm{O}$ interactions were also observed, representing values below $7 \%$. Interactions with the metal source were only observed in 1 
$(\mathrm{M} \cdots \mathrm{N} / \mathrm{N} \cdots \mathrm{M} 2.4 \%), 3(\mathrm{M} \cdots \mathrm{O} / \mathrm{O} \cdots \mathrm{M} 6.9 \%$ and $\mathrm{M} \cdots \mathrm{M} 1.2 \%)$, and $4(\mathrm{M} \cdots \mathrm{O} / \mathrm{O} \cdots \mathrm{M}$ $5.1 \%$ and $\mathrm{M} \cdot \mathrm{M} 1.2 \%$ ) (Figure $14 \mathrm{~b}$ ).

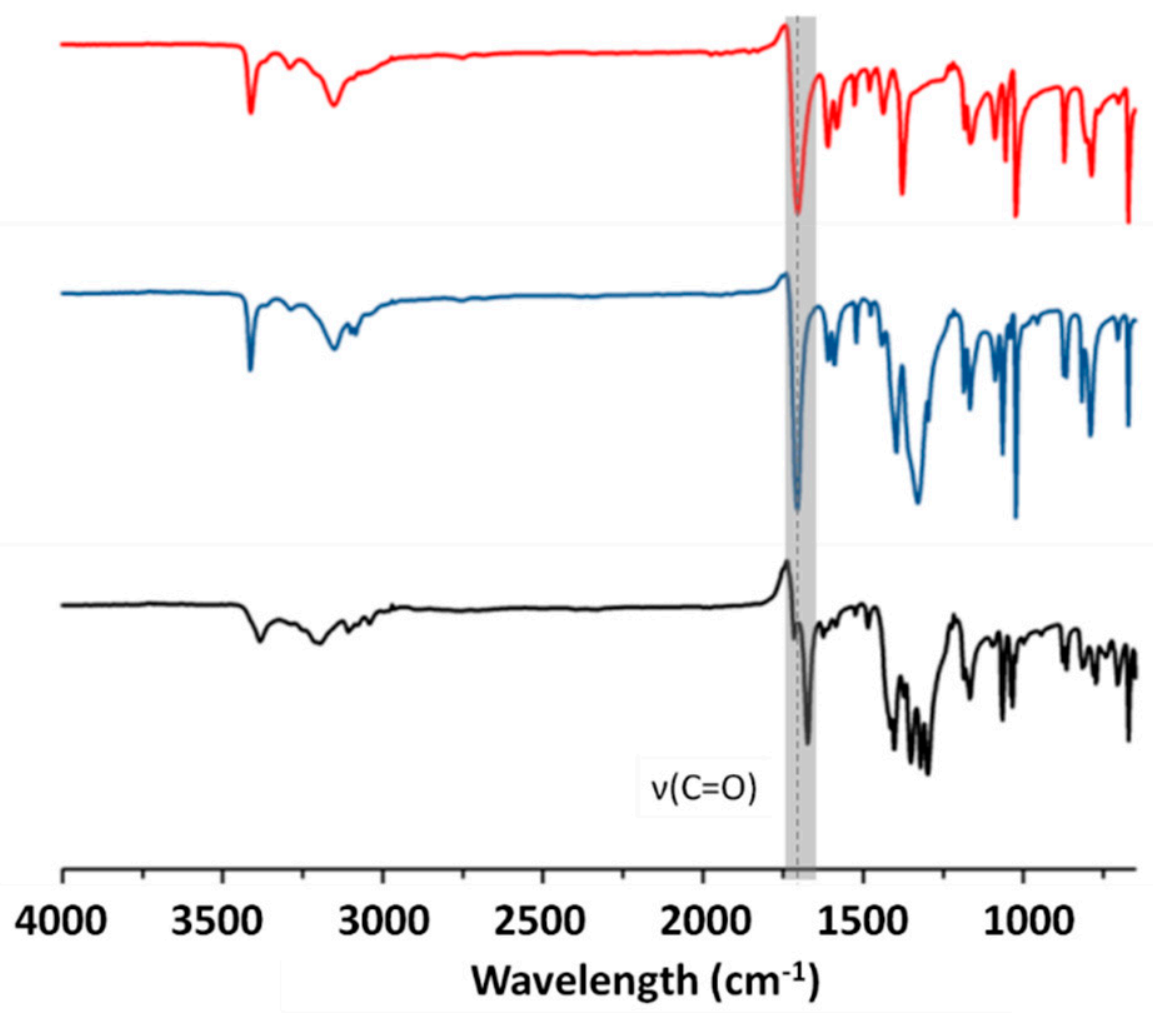

Figure 13. FTIR for pyrazinamide (top) compared with $\mathbf{3}$ (middle) and $\mathbf{5}$ (bottom) (y-axis: transmittance $(\%))$.

a)

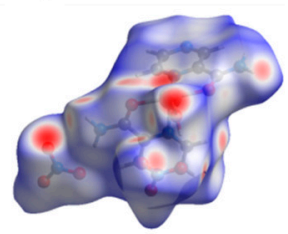

1

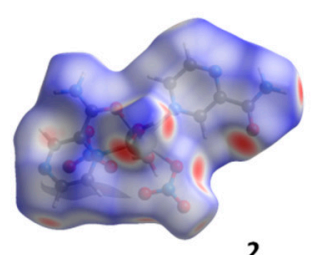

b)

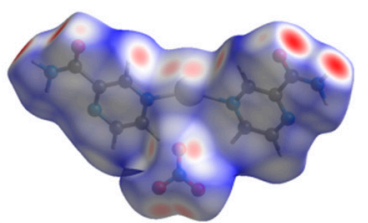

3

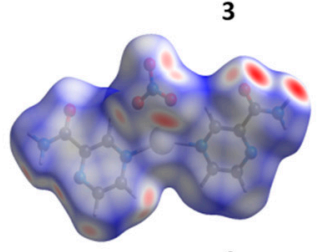

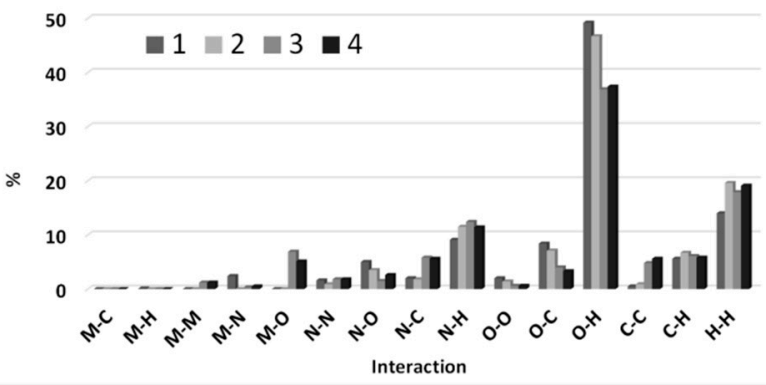

Figure 14. Hirshfeld surfaces for 1-4 (a), and graphical representation of the percentage of the various intermolecular contacts contributing to the Hirshfeld surfaces for 1-4 (b). Reciprocal contacts are included.

\subsection{Shelf and Thermal Stability of Compounds 2, 3, and 5}

The determination of the physicochemical properties of the new compounds was of most relevance if potential pharmaceutical applications were envisaged. The thermal robustness of compounds $\mathbf{2 , 3}$, and 5 was assessed by differential scanning calorimetry and thermogravimetric analysis (DSC/TGA).

The TGA trace of $\mathbf{2}$ showed that it was thermally stable up to ca. $100{ }^{\circ} \mathrm{C}$ (Figure 15), temperature at which the release of the water molecules began, finishing at approximately 
$180{ }^{\circ} \mathrm{C}$ and corresponding to a total weight loss of $8.1 \%$, (theoretical $7.8 \%$ ). From ca. $180{ }^{\circ} \mathrm{C}$ onwards, an important and progressive weight loss of $49.2 \%$ (theoretical $49.9 \%$ ), associated with the complete oxidation and degradation of the organic fraction, was depicted. The final weight loss of $26.3 \%$ (theoretical $26.9 \%$ ) at ca. $380{ }^{\circ} \mathrm{C}$ corresponded to the release of the nitrate ions to form $\mathrm{MnO}$ as a final product, as supported by the percentage of the residues, which was in accordance with the theoretical value of $15.4 \%$ (experimental $16.4 \%$ ) for the remaining $\mathrm{MnO}$.

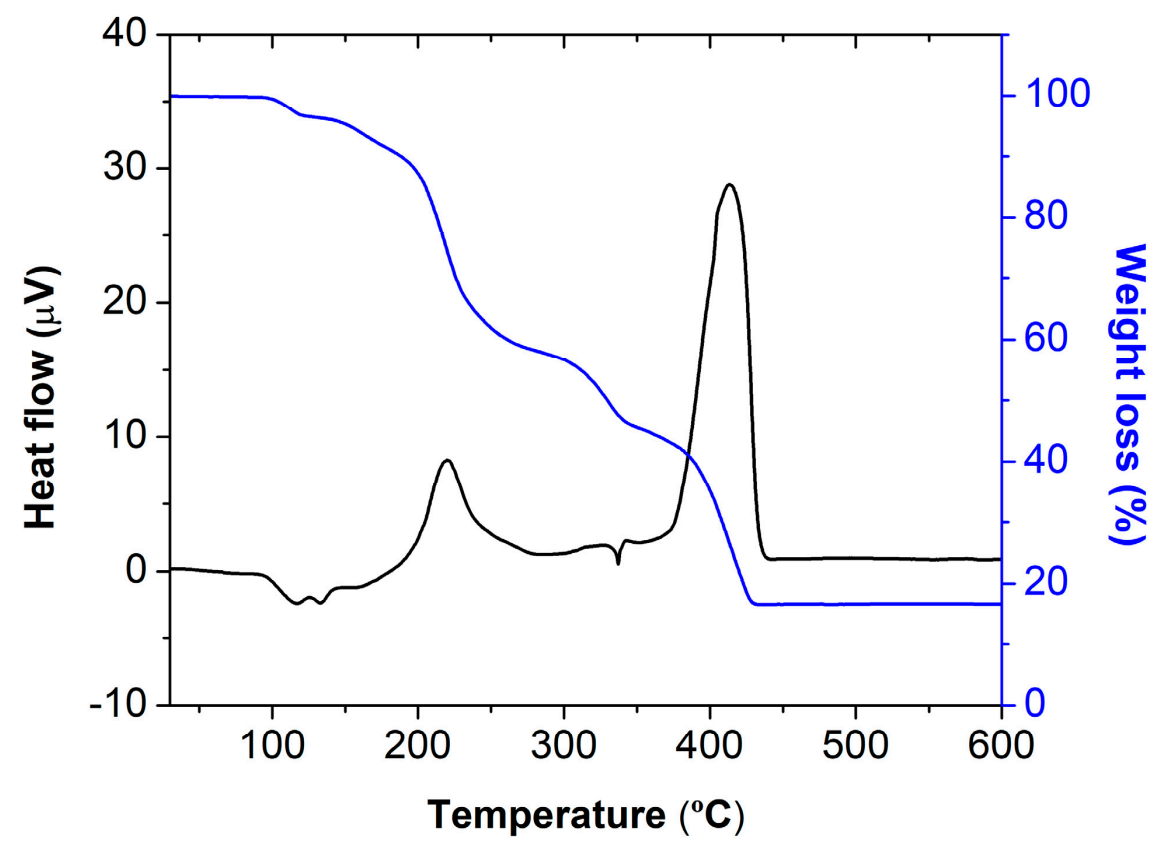

Figure 15. DSC (black) and TGA (blue) of 2.

Regarding 3 and 5, the TGA curves showed that they were both stable until ca. $210{ }^{\circ} \mathrm{C}$, temperature at which the first weight loss was observed (Figure $16 a, b$, respectively). This assured the absence of water (either coordinated or of crystallization) in both compounds. For 5, due to the uncertainty about the crystal structure, further conclusions are not established. In 3, the weight loss of $58.2 \%$ (theoretical $57.3 \%$ ) at ca. $170{ }^{\circ} \mathrm{C}$ was associated with the complete oxidation and degradation of the organic fraction, and the final weight loss of $15.2 \%$ (theoretical $14.9 \%$ ) at ca. $280{ }^{\circ} \mathrm{C}$ corresponded to the release of the nitrate ion. These values were in accordance with the theoretical value of $27.8 \%$ (experimental $26.6 \%$ ) for the remaining $\mathrm{Ag}_{2} \mathrm{O}$.

a)

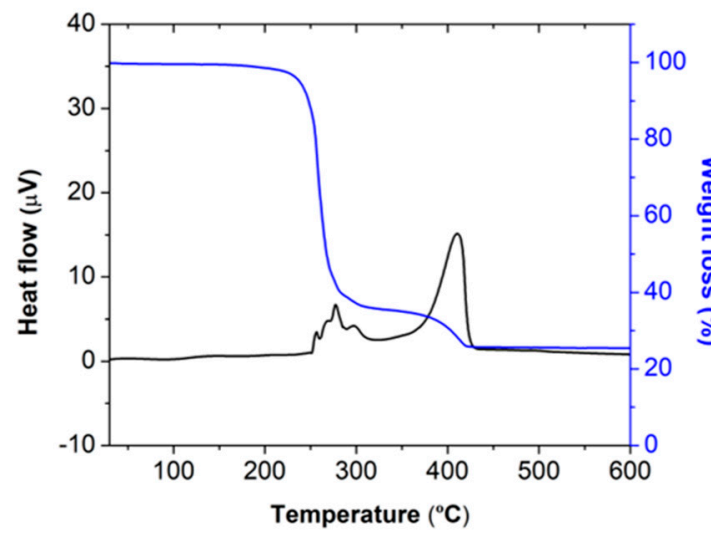

b)

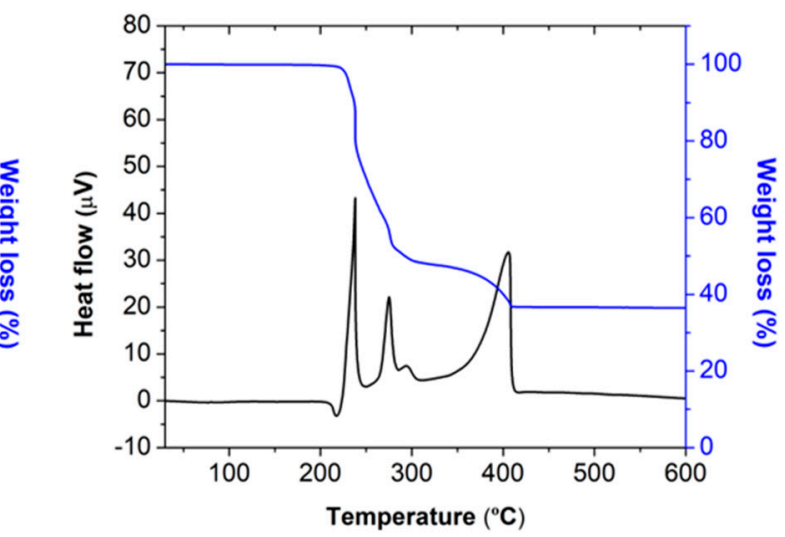

Figure 16. DSC (black) and TGA (blue) of (a) 3 and (b) 5 . 
Regarding the shelf stability of compounds $1-3$, we could conclude that these were stable on the shelf at room temperature for at least 14 months (Figure S11).

\subsection{Antimicrobial Activity of the Compounds}

The synthesized compounds $\mathbf{1}-\mathbf{3}$ and $\mathbf{5}$ and the corresponding starting materials were tested against Escherichia coli (Gram-negative bacteria), Staphylococcus aureus, and Mycobacterium smegmatis (Gram-positive bacteria) to assess their antimicrobial activity. $M$. smegmatis was used as a non-pathogenic model organism of the $M$. tuberculosis, responsible for tuberculosis, which remained a leading cause of death worldwide, both in developing and developed countries. Considering the minimal inhibitory concentration (MIC) values found for each compound (Table 2), it was clear that the silver compounds were the most active, benefiting from the synergistic effects of $\mathrm{Ag}(\mathrm{I})$.

Table 2. Minimal inhibitory concentration (MIC) and minimal bactericidal concentration (MBC) of each reagent and synthesized compound for Escherichia coli (Gram-negative bacteria), Staphylococcus aureus, and Mycobacterium smegmatis (Gram-positive bacteria).

\begin{tabular}{|c|c|c|c|c|c|c|}
\hline \multirow[b]{2}{*}{ Compounds } & \multicolumn{2}{|c|}{ E. coli } & \multicolumn{2}{|c|}{ S. aureus } & \multicolumn{2}{|c|}{ M. smegmatis } \\
\hline & $\begin{array}{c}\text { MIC }^{*} \\
(\mu \mathrm{g} / \mathrm{mL})\end{array}$ & $\begin{array}{c}\text { MBC * } \\
(\mu g / m L)\end{array}$ & $\begin{array}{l}\text { MIC ** } \\
(\mu \mathrm{g} / \mathrm{mL})\end{array}$ & $\begin{array}{c}\mathrm{MBC}^{*} \\
(\mu \mathrm{g} / \mathrm{mL})\end{array}$ & $\begin{array}{l}\text { MIC ** } \\
(\mu \mathrm{g} / \mathrm{mL})\end{array}$ & $\begin{array}{c}\text { MBC * } \\
(\mu \mathrm{g} / \mathrm{mL})\end{array}$ \\
\hline Pyrazinamide & $>62.5$ & 250 & $>250$ & 500 & $>62.5$ & 125 \\
\hline$(1)$ & $>62.5$ & 500 & $>250$ & 500 & $>62.5$ & 62.5 \\
\hline $\mathrm{Zn}\left(\mathrm{NO}_{3}\right)_{2}$ & $>62.5$ & 500 & $>250$ & 500 & $>62.5$ & 62.5 \\
\hline (2) & $>62.5$ & 500 & $>250$ & 500 & $>62.5$ & 125 \\
\hline $\mathrm{Mn}\left(\mathrm{NO}_{3}\right)_{2}$ & $>62.5$ & 500 & $>250$ & 500 & $>62.5$ & 125 \\
\hline (3) & 15.63 & 31.25 & 62.5 & 125 & 15.63 & 31.25 \\
\hline (5) & 7.81 & 31.25 & 62.5 & 125 & 7.81 & 31.25 \\
\hline $\mathrm{AgNO}_{3}$ & 7.81 & 31.25 & 62.5 & 125 & 7.81 & 7.81 \\
\hline Positive control & $\begin{array}{c}<0.49 \\
(\mathrm{NOR})\end{array}$ & $\mathrm{Nd}$ & $\begin{array}{c}0.98 \\
\text { (VAN) }\end{array}$ & $\mathrm{Nd}$ & $\begin{array}{l}<0.49 \\
(\text { VAN) }\end{array}$ & $\mathrm{Nd}$ \\
\hline $\begin{array}{c}\text { Negative } \\
\text { control (DMSO) }\end{array}$ & 62.5 & $\mathrm{Nd}$ & 250 & $\mathrm{Nd}$ & 62.5 & $\mathrm{Nd}$ \\
\hline
\end{tabular}

Legend: NOR—norfloxacin; VAN—vancomycin; Nd-Not determined; * after 24h; ** after 48h. Note: The antimicrobial effect activity of pyrazinamide, $\mathbf{1}, \mathbf{2}$, and the corresponding metal salts are limited by the effect of DMSO.

The preliminary results obtained against the assayed microorganisms showed moderate antimicrobial activity, with the coordination compounds $\mathbf{1}, \mathbf{3}$, and $\mathbf{5}$ showing a significant decrease in the $\mathrm{MBC}$ against $M$. smegmatis. Importantly, the Ag-based compounds 3, and 5 showed a significant increase in the antibacterial activity against the three bacteria strains tested herein. This increase was more pronounced against E. coli and M. smegmatis than against $S$. aureus. A possible explanation for this might be the fact that M. smegmatis presents high similarities to E. coli regarding some cell biology parameters, such as cell volume, ribosome number, and ribosome density [50,51]. Interestingly, genome-based phylogeny studies suggest that mycobacteria are closely related to Gram-positive bacteria but also share properties with Gram-negative bacteria, like the non-retention of the Gram staining [52].

Looking specifically to the MIC values obtained for M. smegmatis, it is clear that coordination compounds $\mathbf{3}$ and $\mathbf{5}$ display antimycobacterial activity four to eight times higher than the free pyrazinamide, respectively.

These promising outcomes result from the synergistic effect between the antibiotic itself and $\operatorname{Ag}(\mathrm{I})$, a metal known for its own antimicrobial effects. The proximity between the minimum bactericidal concentrations and the minimum inhibitory concentration values for both 3 and $\mathbf{5}$ reveal their bactericidal effect against the three tested microorganisms. The obtained results emphasize the importance of this type of antibacterial coordination frameworks to augment the antibacterial activity of already commercially available antibiotics, especially to fight diseases with a huge socio-economic impact like tuberculosis. 


\section{Experimental Details}

\subsection{Reagents}

The following reagents and solvents were purchased from commercial sources and used without further purification-pyrazinamide $\left(\mathrm{C}_{5} \mathrm{H}_{5} \mathrm{~N}_{3} \mathrm{O}, 97.5 \%\right.$ Sigma-Aldrich, $\mathrm{Mu}-$ nich, Germany), zinc nitrate hexahydrate $\left(\mathrm{Zn}\left(\mathrm{NO}_{3}\right) 6 \mathrm{H}_{2} \mathrm{O}, 98.5-102 \%\right.$, Scharlau, Barcelona, Spain), manganese nitrate tetrahydrate $\left(\mathrm{Mn}\left(\mathrm{NO}_{3}\right)_{2} .4 \mathrm{H}_{2} \mathrm{O}, 98 \%\right.$, Alfa Aesar, Germany), silver nitrate $\left(\mathrm{AgNO}_{3}, 99 \%\right.$, Merck, Darmstadt, Germany), methanol $\left(\mathrm{CH}_{3} \mathrm{OH}, 99.9 \%\right.$, Carlo-Erba, Chaussée du Vexin, France), ethanol $\left(\mathrm{C}_{2} \mathrm{H}_{5} \mathrm{OH}, 99 \%\right.$, Carlo-Erba, Chaussée $\mathrm{du}$ Vexin, France), acetone $\left(\mathrm{C}_{3} \mathrm{H}_{6} \mathrm{O}, 99,8 \%\right.$, Merck, Darmstadt, Germany), and dimethyl sulfoxide (DMSO, 99\%, Fluka, Buchs, Switzerland).

\subsection{Synthesis of the Compounds}

The reaction products $\mathbf{1}-\mathbf{3}$ and $\mathbf{5}$ were synthesized via neat grinding using pyrazinamide and different metal salts $\left(\mathrm{Mn}\left(\mathrm{NO}_{3}\right)_{2} 4 \mathrm{H}_{2} \mathrm{O}, \mathrm{Zn}\left(\mathrm{NO}_{3}\right)_{2} 6 \mathrm{H}_{2} \mathrm{O}\right.$ and $\left.\mathrm{AgNO}_{3}\right)$ for the defined periods of time listed in Table 3. The reactions were carried out in a Retsch MM400 ball mill operating at $28 \mathrm{~s}^{-1}$, using two $7 \mathrm{~mm}$ stainless steel balls inside $15 \mathrm{~mL}$ stainless steel grinding jars, with a snap closure.

Table 3. Neat grinding experimental conditions for the synthesis of compounds 1-3 and 5 .

\begin{tabular}{|c|c|c|c|c|}
\hline $\begin{array}{l}\text { Pyrazinamide } \\
\text { (PYR) }\end{array}$ & Metal Salt (M) & $\begin{array}{c}\text { Molar Ratio } \\
\text { (PYR:M) }\end{array}$ & Time & Resulting Compound \\
\hline $\begin{array}{c}0.0907 \mathrm{~g} \\
(0.74 \mathrm{mmol})\end{array}$ & $\begin{array}{c}\mathrm{Zn}\left(\mathrm{NO}_{3}\right)_{2} \cdot 6 \mathrm{H}_{2} \mathrm{O} \\
0.1105 \mathrm{~g} \\
(0.37 \mathrm{mmol})\end{array}$ & $2: 1$ & $10 \mathrm{~min}$ & (1) \\
\hline $\begin{array}{c}0.0992 \mathrm{~g} \\
(0.81 \mathrm{mmol})\end{array}$ & $\begin{array}{c}\mathrm{Mn}\left(\mathrm{NO}_{3}\right)_{2} \cdot 4 \mathrm{H}_{2} \mathrm{O} \\
0.1036 \mathrm{~g} \\
(0.41 \mathrm{mmol})\end{array}$ & $2: 1$ & \multirow{3}{*}{$15 \mathrm{~min}$} & $(2)$ \\
\hline $\begin{array}{c}0.1183 \mathrm{~g} \\
(0.96 \mathrm{mmol})\end{array}$ & $\begin{array}{c}\mathrm{AgNO}_{3} \\
0.0829 \mathrm{~g} \\
(0.49 \mathrm{mmol})\end{array}$ & $2: 1$ & & (3) \\
\hline $\begin{array}{c}0.0840 \mathrm{~g} \\
(0.68 \mathrm{mmol})\end{array}$ & $\begin{array}{c}\mathrm{AgNO}_{3} \\
0.1171 \mathrm{~g} \\
(0.69 \mathrm{mmol})\end{array}$ & $1: 1$ & & (5) \\
\hline
\end{tabular}

Compound 4 was obtained in the recrystallization of 3 in water, through slow evaporation of the solvent, at room temperature.

\subsection{General Characterization}

Powder X-Ray Diffraction (PXRD) data were collected in a D8 Advance Bruker AXS $\theta-2 \theta$ diffractometer (Bruker, Karlsruhe, Germany), equipped with a LYNXEYE-XE detector, copper radiation source $(\mathrm{Cu} \mathrm{K} \alpha, \lambda=1.5406 \AA)$, operated at $40 \mathrm{kV}$ and $30 \mathrm{~mA}$, with the following data collection parameters $-3-60^{\circ} 2 \theta$ range, a step size of $0.02^{\circ}$, and $0.6 \mathrm{~s}$ per step and $3-37^{\circ} 2 \theta$ range, step size of $0.02^{\circ}$ and $0.5 \mathrm{~s}$ per step. The diffractograms were used to ascertain bulk material purity of the compounds 1-3, by comparing the calculated (from SCXRD data) and experimental PXRD patterns, and to ascertain the formation of the new reaction product (5), in comparison with the starting materials. MERCURY 2020.2.0 [53] was used to obtain the diffraction patterns of the pyrazinamide polymorphs and of the calculated pattern obtained from single-crystal data.

Fourier Transform Infrared Spectroscopy (FTIR) measurements were recorded on a Thermo Nicolet 6700 spectrometer (Waltham, MA, USA) with attenuated total reflectance (ATR) mode by averaging 32 scans at a maximum resolution of $4 \mathrm{~cm}^{-1}$, registering the spectra at a wavelength interval of $4000-650 \mathrm{~cm}^{-1}$. 
Combined Thermogravimetric Analysis-Differential Scanning Calorimetric (TGADSC) were carried out using a Setsys Evo 16 SETARAM TG-DTA 92 thermobalance (Caluire, France) under air flow, with a heating rate of $10{ }^{\circ} \mathrm{C} \mathrm{min}^{-1}$. The samples weights were in the $8-20 \mathrm{mg}$ range.

\subsection{Single Crystal X-ray Diffraction Studies (SCXRD)}

Suitable single crystals of 2, 3, and 4 were obtained by slow evaporation of the assynthesized products from acetone, water, and methanol solution, respectively. Crystal structures of 2, 3, and 4 were determined from SCXRD data. Data were collected on a Bruker AXS-KAPPA APEX II (Bruker, Karlsruhe, Germany), with graphite-monochromated radiation $(\mathrm{Mo} \mathrm{K} \alpha, \lambda=0.71073 \AA$ ) $)$ at $293 \mathrm{~K}$. X-ray generator was operated at $50 \mathrm{kV}$ and $30 \mathrm{~mA}$ and the APEX2 program was monitored for data collection. Data were corrected for Lorentzian polarization and absorption effects using SAINT [54] and SADABS [55] programs. SHELXT 2014/4 [56] was used for structure solution and SHELXL 2014/7 [57] was used for full matrix least-squares refinement on $F^{2}$. These two programs were included in the WINGX-Version 2014.1 [58] program package. A full-matrix least-squares refinement was used for the non-hydrogen atoms with anisotropic thermal parameters. The $\mathrm{H}_{\mathrm{CH}}$ were inserted in idealized positions and allowed to refine in the parent carbon atom. The hydrogen atoms of the $\mathrm{NH}_{2}$ group of $\mathbf{2}$ and $\mathbf{4}$ and of the water molecules of 2 were located from the electron density map and allowed to refine freely. Additionally, in 3 , the $\mathrm{NH}_{2}$ group was located from the electron density map but the $\mathrm{N}-\mathrm{H}$ distances were restrained. MERCURY 2020.2.0 [53] was used for packing diagrams and for polyhedral representation. PLATON [59] was used for the determination of hydrogen bond interactions. Table 4 summarizes the data collection and refinement details. Crystallographic data of complexes 2, 3, and 4 were deposited at the Cambridge Crystallographic Data Centre (CCDC 2063304-2063306).

\subsection{Antibacterial Activity Assays}

Gram-negative (Escherichia coli (ATCC 25922) and Gram-positive bacteria (Staphylococcus aureus (ATCC 25923) and Mycobacterium smegmatis (ATCC 607)) were selected as model organisms for the determination of the minimum inhibitory and bactericidal concentrations (MIC and MBC, respectively) of the synthesized compounds and respective starting materials.

These values were determined by the microdilution method [60,61]. In brief, $100 \mu \mathrm{L}$ of the Mueller-Hinton liquid culture medium were added to all 96-wells of the microplate, and $100 \mu \mathrm{L}$ of the testing compounds at a concentration of $1 \mathrm{mg} \cdot \mathrm{mL}^{-1}$ in DMSO were added to the first well. Serial dilutions of (1:2) were performed and $10 \mu \mathrm{L}$ of bacterial inoculum was added to each well. Then, the microplates were incubated for $24 \mathrm{~h}$ and $48 \mathrm{~h}$, at $37^{\circ} \mathrm{C}$. After $24 \mathrm{~h}$ or $48 \mathrm{~h}$, the plates were visually analyzed and the lower concentration well, where no visible bacterial growth could be detected, was considered as the MIC value. Then, the content of the wells without active bacterial growth (within the range concentrations equal and higher to the MIC) was used as inoculum to be spread onto a new sterile Mueller-Hinton solid culture medium plates. These solid medium plates were incubated at $37^{\circ} \mathrm{C}$ for $24 \mathrm{~h}$, to allow $\mathrm{MBC}$ value determination, which was the lowest concentration with no visible bacterial growth. 
Table 4. Crystallographic data for $\mathbf{2}-\mathbf{4}$.

\begin{tabular}{|c|c|c|c|}
\hline & 2 & 3 & 4 \\
\hline Chemical formula & $\mathrm{C}_{10} \mathrm{H}_{10} \mathrm{~N}_{6} \mathrm{O}_{2} \mathrm{Mn} \cdot 2 \mathrm{H}_{2} \mathrm{O} \cdot 2 \mathrm{NO}_{3}$ & $\mathrm{C}_{10} \mathrm{H}_{10} \mathrm{~N}_{6} \mathrm{O}_{2} \mathrm{Ag} \cdot \mathrm{NO}_{3}$ & $\mathrm{C}_{10} \mathrm{H}_{10} \mathrm{~N}_{6} \mathrm{O}_{2} \mathrm{Ag} \cdot \mathrm{NO}_{3}$ \\
\hline Formula weight & 461.23 & 416.12 & 416.12 \\
\hline Temperature (K) & 293 & 293 & 293 \\
\hline Wavelength $(\AA)$ & 0.71073 & 0.71073 & 0.71073 \\
\hline Crystal form, color & Block, colorless & Block, colorless & Plate, colorless \\
\hline Crystal size (mm) & $0.17 \times 0.08 \times 0.03$ & $0.14 \times 0.10 \times 0.10$ & $0.12 \times 0.12 \times 0.10$ \\
\hline Crystal system & Triclinic & Monoclinic & Monoclinic \\
\hline Space group & $P \overline{1}$ & $P 2_{1} / m$ & $P 2 / c$ \\
\hline$a(\AA)$ & $6.9866(3)$ & $3.6132(11)$ & $3.5903(4)$ \\
\hline$b(\AA)$ & $9.2273(4)$ & $27.735(8)$ & $6.7181(6)$ \\
\hline$c(\AA)$ & $14.1882(5)$ & $6.6273(19)$ & $27.610(3)$ \\
\hline$\alpha\left(^{\circ}\right)$ & $90.584(3)$ & 90.00 & 90.00 \\
\hline$\beta\left(^{\circ}\right)$ & $99.285(2)$ & $94.007(9)$ & $91.149(5)$ \\
\hline$\gamma\left({ }^{\circ}\right)$ & $101.460(2)$ & 90.00 & 90.00 \\
\hline$V\left(\AA^{3}\right)$ & $883.85(6)$ & $662.5(3)$ & $665.81(11)$ \\
\hline Z & 2 & 2 & 2 \\
\hline$d\left(\mathrm{mg} \cdot \mathrm{m}^{-3}\right)$ & 1.733 & 2.086 & 2.076 \\
\hline$\mu\left(\mathrm{mm}^{-1}\right)$ & 0.820 & 1.564 & 1.556 \\
\hline$F(000)$ & 470 & 412 & 412 \\
\hline$\theta$ range $\left(^{\circ}\right)$ & $2.630-30.976$ & $3.081-26.510$ & $2.952-26.563$ \\
\hline Reflections collected/unique & $15432 / 5513$ & $4443 / 1381$ & $5186 / 1374$ \\
\hline $\mathrm{R}_{\text {int }}$ & 0.0349 & 0.0470 & 0.0301 \\
\hline GOF & 1.020 & 1.132 & 1.217 \\
\hline Final $\mathrm{R}$ indices $[I>2 \sigma(I)]$ & $\mathrm{R}_{1}=0.0357, \mathrm{wR}_{2}=0.0892$ & $\mathrm{R}_{1}=0.0630, \mathrm{wR}_{2}=0.1316$ & $\mathrm{R}_{1}=0.0577, \mathrm{wR}_{2}=0.1256$ \\
\hline Indices all data & $\mathrm{R}_{1}=0.0476, \mathrm{w} \mathrm{R}_{2}=0.0938$ & $\mathrm{R}_{1}=0.0780, \mathrm{w} \mathrm{R}_{2}=0.1372$ & $\mathrm{R}_{1}=0.0620, \mathrm{w} \mathrm{R}_{2}=0.1273$ \\
\hline
\end{tabular}

\section{Conclusions}

Neat grinding successfully led to the formation of four novel compounds, 2-5, and the reproduction of 1 . Even though 1, a $1 \mathrm{D}$ framework with $\mathrm{Zn}(\mathrm{II})$, was previously disclosed [34,49], herein we proposed mechanochemistry as a sustainable alternative for the synthetic procedure. Compounds 2-5 were unveiled for the first time herein, but the full structural elucidation was only possible for 2,3 , and 4 , due to the impossibility of growing good quality single crystals of 5 . For 4 , only its structural characterization was possible due to the low amount of sample obtained.

With $\mathrm{Zn}(\mathrm{II})$ and $\mathrm{Ag}(\mathrm{I})$ nitrates, the (2:1) stoichiometry directly led to the formation of 1D coordination frameworks ( 1 and 4 ), while the final product resulting from the reaction with Mn(II) nitrate corresponded to a complex (2), as well as 3, which results from the reaction with $\operatorname{Ag}(\mathrm{I})$ nitrate. Nevertheless, in 1-4, hydrogen bonding frameworks were formed. Furthermore, it was noticed that, as a ligand, pyrazinamide was able to generate different coordination modes. With $\mathrm{Zn}(\mathrm{II})$ (1) and Mn(II) (2), it coordinated via both the $\mathrm{N}, \mathrm{O}$-amide moiety and the pyrazine-N atoms, while with $\mathrm{Ag}(\mathrm{I})$ (3 and 4$)$ it only coordinated by the pyrazine-N atom.

Compounds 2,3 , and 5 were stable on shelf for at least 14 months and they were also stable at least until $100{ }^{\circ} \mathrm{C}$. Compound 2 was thermally stable up to ca. $100{ }^{\circ} \mathrm{C}$ temperature, when the water molecules were released from the structure. Compounds 3 and 5 were stable until ca. $200{ }^{\circ} \mathrm{C}$, confirming the absence of water molecules in $\mathbf{3}$ and also proving that absence in 5 .

These compounds were promising with regards to the improvement of pharmaceutical properties compared to the free antibiotic and these results were indeed encouraging to further study potential applications in the pharmaceutical field. Even though the MBC value obtained with 1, in which $\mathrm{Zn}$ was used, already represented an asset, the best results were indeed obtained with the Ag-based compounds. The antimicrobial activity tests showed that the Ag-pyrazinamide compounds $\mathbf{3}$ and $\mathbf{5}$ displayed at least four times higher antibiotic activity than pyrazinamide against E. coli (a Gram-negative model bacteria), $S$. 
aureus (a Gram-positive model bacteria), and M. smegmatis (a Gram-positive non-pathogenic bacteria used as a model on the Mycobacterium genus works). The bactericidal effect obtained with these two compounds is an additional positive result that encourages further studies with similar compounds.

Supplementary Materials: The following are available online. Figure S1. PXRD patterns of the experimental (top) (1) and simulated (bottom) of HAYKUP; Figure S2. PXRD patterns of the experimental (top) and simulated (bottom) 2; Figure S3. PXRD patterns of the experimental (top) and simulated (bottom) 3; Figure S4. PXRD patterns of the simulated crystal of 4 (top) compared with the experimental 3 (bottom); Figure S5. PXRD patterns of the experimental of 5 (red) compared with its diffractogram after 11 months in shelf conditions (blue), 3 (black), pyrazinamide (green) and AgNO3 (purple), confirming the formation of the new reaction product, 5; Figure S6. 2D fingerprint plots for 1 for the most relevant interactions. Reciprocal contacts are included; Figure S7. 2D fingerprint plots for 2 for the most relevant interactions. Reciprocal contacts are included Figure S8. 2D fingerprint plots for 3 for the most relevant interactions. Reciprocal contacts are included; Figure S9. 2D fingerprint plots for 4 for the most relevant interactions. Reciprocal contacts are included; Figure S10. Percentage of various intermolecular contacts contributing to the Hirshfeld surfaces for 1-4. Reciprocal contacts are included; Figure S11. PXRD patterns of the experimental (red), after 14 months on the shelf at room conditions (blue) and the respective simulated diffractogram from the crystal structure (black) for the synthesised new compounds (a) 1, (b) 2, (c) 3 and (d) 5. For compound 5, the experimental diffractograms (red and blue) are compared with the starting materials: pyrazinamide (black) and silver nitrate (grey), as its structural elucidation was not possible; Table S1. Selected bond lengths $(\AA)$ and angles $\left({ }^{\circ}\right)$ for 1 ; Table S2. Selected bond lengths $(\AA)$ and angles $\left(^{\circ}\right)$ for 2; Table S3. Selected bond lengths $(\AA)$ and angles $\left({ }^{\circ}\right)$ for 3; Table S4. Selected bond lengths $(\AA)$ and angles $\left(^{\circ}\right)$ for 4 .

Author Contributions: Conceptualization, V.A., M.T.D. and S.Q.; methodology, S.Q., V.A. and P.C.A.; formal analysis, S.Q., V.A. and P.C.A.; investigation, S.Q. and P.C.A.; data curation, S.Q., V.A., P.C.A. and P.R.; writing-original draft preparation, S.Q. and P.C.A.; writing-review and editing, V.A., P.R. and M.T.D.; supervision, M.T.D., P.R. and V.A.; project administration, V.A., M.T.D.; funding acquisition, V.A., P.R. and M.T.D. All authors have read and agreed to the published version of the manuscript.

Funding: The authors acknowledge Fundação para a Ciência e a Tecnologia (FCT, Portugal) (projects UIDB/00100/2020, UIDP/00100/2020, UID/QUI/00100/2019, UIDP/04567/2020, UIDB/04567/2020, and PTDC/QUI-OUT/30988/2017, grant SFRH/BD/100029/2014, and contracts under DL No. 57/2016 regulation and the CEECIND program - CEECIND/00283/2018) and FEDER, Portugal 2020 and Lisboa2020 for funding (project LISBOA-01-0145-FEDER-030988 and contract under DL No. 57/2016 regulation).

Data Availability Statement: Crystallographic data of compounds 2-4 were deposited at the Cambridge Crystallographic Data Centre (CCDC 2063304-2063306).

Acknowledgments: The authors acknowledge Auguste Fernandes for the DSC/TGA and FTIR data.

Conflicts of Interest: The authors declare no conflict of interest.

\section{References}

1. Zhang, Y.; Mitchison, D. The curious characteristics of pyrazinamide: A review. Int. J. Tuberc. Lung Dis. 2003, 7, 6-21. [PubMed]

2. Somoskovi, A.; Wade, M.M.; Sun, Z.; Zhang, Y. Iron enhances the antituberculous activity of pyrazinamide. J. Antimicrob. Chemother. 2004, 53, 192-196. [CrossRef] [PubMed]

3. Cavalcante, S.; Chakaya, J.M.; Egwaga, S.M.; Gie, R.; Gondrie, P.; Harries, A.D.; Hopewell, P.; Kumar, B.; Weezenbeck, K.L.-v.; Mase, S.; et al. Treatment of tuberculosis: Guidelines, 4th ed.; World Health Organization: Geneva, Switzerland, 2010.

4. World Health Organization Model List of Essential Medicines, 21st List; World Health Organization: Geneva, Switzerland, 2019. Available online: https:/ / apps.who.int/iris/bitstream/handle/10665/325771/WHO-MVP-EMP-IAU-2019.06-eng.pdf?ua=1 (accessed on 15 January 2021).

5. A Mitchison, D.; Davies, G. The chemotherapy of tuberculosis: Past, present and future [State of the art]. Int. J. Tuberc. Lung Dis. 2012, 16, 724-732. [CrossRef]

6. Eddaoudi, M.; Sava, D.F.; Eubank, J.F.; Adil, K.; Guillerm, V. Zeolite-like metal-organic frameworks (ZMOFs): Design, synthesis, and properties. Chem. Soc. Rev. 2015, 44, 228-249. [CrossRef] 
7. Guillerm, V.; Kim, D.; Eubank, J.F.; Luebke, R.; Liu, X.; Adil, K.; Lah, M.S.; Eddaoudi, M. A supermolecular building approach for the design and construction of metal-organic frameworks. Chem. Soc. Rev. 2014, 43, 6141-6172. [CrossRef]

8. Eddaoudi, M.; Moler, D.B.; Li, H.; Chen, B.; Reineke, T.M.; O'Keeffe, M.; Yaghi, O.M. Modular Chemistry: Secondary Building Units as a Basis for the Design of Highly Porous and Robust Metal-Organic Carboxylate Frameworks. Accounts Chem. Res. 2001, 34, 319-330. [CrossRef]

9. Miller, S.R.; Heurtaux, D.; Baati, T.; Horcajada, P.; Grenèche, J.-M.; Serre, C. Biodegradable therapeutic MOFs for the delivery of bioactive molecules. Chem. Commun. 2010, 46, 4526-4528. [CrossRef]

10. Li, S.; Huo, F. Metal-organic framework composites: From fundamentals to applications. Nanoscale 2015, 7, 7482-7501. [CrossRef] [PubMed]

11. Lee, J.; Farha, O.K.; Roberts, J.; Scheidt, K.A.; Nguyen, S.T.; Hupp, J.T. Metal-organic framework materials as catalysts. Chem. Soc. Rev. 2009, 38, 1450-1459. [CrossRef] [PubMed]

12. Sun, C.-Y.; Qin, C.; Wang, X.-L.; Su, Z.-M. Metal-organic frameworks as potential drug delivery systems. Expert Opin. Drug Deliv. 2012, 10, 89-101. [CrossRef]

13. Wang, S.; Wang, X. Multifunctional Metal-Organic Frameworks for Photocatalysis. Small 2015, 11, 3097-3112. [CrossRef]

14. Wuttke, S.; Braig, S.; Preiß, T.; Zimpel, A.; Sicklinger, J.; Bellomo, C.; Rädler, J.O.; Vollmar, A.M.; Bein, T. MOF nanoparticles coated by lipid bilayers and their uptake by cancer cells. Chem. Commun. 2015, 51, 15752-15755. [CrossRef]

15. Wang, X.-G.; Dong, Z.-Y.; Cheng, H.; Wan, S.-S.; Chen, W.-H.; Zou, M.-Z.; Huo, J.-W.; Deng, H.-X.; Zhang, X.-Z. A multifunctional metal-organic framework based tumor targeting drug delivery system for cancer therapy. Nanoscale 2015, 7, 16061-16070. [CrossRef]

16. Imaz, I.; Rubio-Martínez, M.; An, J.; Solé-Font, I.; Rosi, N.L.; Maspoch, D. Metal-biomolecule frameworks (MBioFs). Chem. Commun. 2011, 47, 7287-7302. [CrossRef]

17. Horcajada, P.; Gref, R.; Baati, T.; Allan, P.K.; Maurin, G.; Couvreur, P.; Férey, G.; Morris, R.E.; Serre, C. Metal-Organic Frameworks in Biomedicine. Chem. Rev. 2011, 112, 1232-1268. [CrossRef]

18. McKinlay, A.C.; Morris, R.E.; Horcajada, P.; Férey, G.; Gref, R.; Couvreur, P.; Serre, C. BioMOFs: Metal-Organic Frameworks for Biological and Medical Applications. Angew. Chem. Int. Ed. 2010, 49, 6260-6266. [CrossRef] [PubMed]

19. Horcajada, P.; Serre, C.; Vallet-Regí, M.; Sebban, M.; Taulelle, F.; Férey, G. Metal-Organic Frameworks as Efficient Materials for Drug Delivery. Angew. Chem. Int. Ed. 2006, 45, 5974-5978. [CrossRef] [PubMed]

20. Horcajada, P.; Serre, C.; Maurin, G.; Ramsahye, N.A.; Balas, F.; Vallet-Regí, M.; Sebban, M.; Taulelle, F.; Férey, G. Flexible Porous Metal-Organic Frameworks for a Controlled Drug Delivery. J. Am. Chem. Soc. 2008, 130, 6774-6780. [CrossRef] [PubMed]

21. Babarao, R.; Jiang, J. Unraveling the Energetics and Dynamics of Ibuprofen in Mesoporous Metal-Organic Frameworks. J. Phys. Chem. C 2009, 113, 18287-18291. [CrossRef]

22. An, J.; Geib, S.J.; Rosi, N.L. Cation-Triggered Drug Release from a Porous Zinc-Adeninate Metal-Organic Framework. J. Am. Chem. Soc. 2009, 131, 8376-8377. [CrossRef]

23. Alves, P.C.; Rijo, P.; Bravo, C.; Antunes, A.M.M.; André, V. Bioactivity of Isostructural Hydrogen Bonding Frameworks Built from Pipemidic Acid Metal Complexes. Molecules 2020, 25, 2374. [CrossRef]

24. Andre, V.; Da Silva, A.R.F.; Fernandes, A.; Frade, R.; Garcia, C.; Rijo, P.; Antunes, A.M.M.; Rocha, J.; Duarte, M.T. Mg- and Mn-MOFs Boost the Antibiotic Activity of Nalidixic Acid. ACS Appl. Bio Mater. 2019, 2, 2347-2354. [CrossRef]

25. Quaresma, S.; André, V.; Antunes, A.M.M.; Vilela, S.M.F.; Amariei, G.; Arenas-Vivo, A.; Rosal, R.; Horcajada, P.; Duarte, M.T. Novel Antibacterial Azelaic Acid BioMOFs. Cryst. Growth Des. 2019, 20, 370-382. [CrossRef]

26. André, V.; Galego, F.; Martins, M. Mechanochemical Assembly of Nalidixic Acid Bioinspired Metal-Organic Compounds and Complexes toward Improved Solubility. Cryst. Growth Des. 2018, 18, 2067-2081. [CrossRef]

27. Amidon, G.L.; Lennernäs, H.; Shah, V.P.; Crison, J.R. A Theoretical Basis for a Biopharmaceutic Drug Classification: The Correlation of in Vitro Drug Product Dissolution and in Vivo Bioavailability. Pharm. Res. 1995, 12, 413-420. [CrossRef]

28. Khadka, P.; Ro, J.; Kim, H.; Kim, I.; Kim, J.T.; Kim, H.; Cho, J.M.; Yun, G.; Lee, J. Pharmaceutical particle technologies: An approach to improve drug solubility, dissolution and bioavailability. Asian J. Pharm. Sci. 2014, 9, 304-316. [CrossRef]

29. Hu, J.; Johnston, K.P.; Williams, R.O. Nanoparticle Engineering Processes for Enhancing the Dissolution Rates of Poorly Water Soluble Drugs. Drug Dev. Ind. Pharm. 2004, 30, 233-245. [CrossRef] [PubMed]

30. Costa, P.; Lobo, J.M.S. Modeling and comparison of dissolution profiles. Eur. J. Pharm. Sci. 2001, 13, 123-133. [CrossRef]

31. Salehi, S.; Moghaddam, S.M.M.; Tarin, M.; Saljooghi, A.S. Pharmaceutical Nickel (II) Chelation Properties of 3-Hydroxyflaven, Deferiprone and Maltol Metal Chelators: A Density Functional Study. Phys. Chem. Res. 2020, 8, 91-110. [CrossRef]

32. Tran, Q.H.; Doan, T.T. A novel study on curcumin metal complexes: Solubility improvement, bioactivity, and trial burn wound treatment in rats. New J. Chem. 2020, 44, 13036-13045. [CrossRef]

33. Abdolmaleki, S.; Ghadermazi, M.; Ashengroph, M.; Saffari, A.; Sabzkohi, S.M. Cobalt (II), zirconium(IV), calcium(II) complexes with dipicolinic acid and imidazole derivatives: X-ray studies, thermal analyses, evaluation as in vitro antibacterial and cytotoxic agents. Inorganica Chim. Acta 2018, 480, 70-82. [CrossRef]

34. Allen, F.H. The Cambridge Structural Database: A quarter of a million crystal structures and rising. Acta Crystallogr. Sect. B Struct. Sci. 2002, 58, 380-388. [CrossRef] 
35. Tabrizi, L.; Chiniforoshan, H.; McArdle, P. A novel one-dimensional manganese(II) coordination polymer containing both dicyanamide and pyrazinamide ligands: Synthesis, spectroscopic investigations, $X$-ray studies and evaluation of biological activities. Spectrochim. Acta Part A Mol. Biomol. Spectrosc. 2015, 139, 307-312. [CrossRef] [PubMed]

36. Ali, M.; Ahmed, M.; Hafiz, S.; Kamal, M.; Mumtaz, M.; Ayatollahi, S.A. Design, Synthesis and Antitubercular Evaluation of Novel Series of Pyrazinecarboxamide Metal Complexes. IJPR 2018, 17, 93-99.

37. Stenger-Smith, J.; Kamariza, M.; Chakraborty, I.; Ouattara, R.; Bertozzi, C.R.; Mascharak, P.K. Enhanced Bactericidal Effects of Pyrazinamide Toward Mycobacterium smegmatis and Mycobacterium tuberculosis upon Conjugation to a $\{\mathrm{Au}(\mathrm{I})-$ triphenylphosphine\}+ Moiety. ACS Omega 2020, 5, 6826-6833. [CrossRef]

38. Titi, H.M.; Do, J.-L.; Howarth, A.J.; Nagapudi, K.; Friščić, T. Simple, scalable mechanosynthesis of metal-organic frameworks using liquid-assisted resonant acoustic mixing (LA-RAM). Chem. Sci. 2020, 11, 7578-7584. [CrossRef]

39. Friščić, T.; Mottillo, C.; Titi, H.M. Mechanochemistry for Synthesis. Angew. Chem. Int. Ed. 2020, 59, 1018-1029. [CrossRef] [PubMed]

40. Hasa, D.; Rauber, G.S.; Voinovich, D.; Jones, W. Cocrystal Formation through Mechanochemistry: From Neat and Liquid-Assisted Grinding to Polymer-Assisted Grinding. Angew. Chem. Int. Ed. 2015, 54, 7371-7375. [CrossRef]

41. James, S.L.; Adams, C.J.; Bolm, C.; Braga, D.; Collier, P.; Friščić, T.; Grepioni, F.; Harris, K.D.M.; Hyett, G.; Jones, W.; et al. Mechanochemistry: Opportunities for new and cleaner synthesis. Chem. Soc. Rev. 2011, 41, 413-447. [CrossRef] [PubMed]

42. Hasa, D.; Carlino, E.; Jones, W. Polymer-Assisted Grinding, a Versatile Method for Polymorph Control of Cocrystallization. Cryst. Growth Des. 2016, 16, 1772-1779. [CrossRef]

43. Friščić, T. New opportunities for materials synthesis using mechanochemistry. J. Mater. Chem. 2010, 20, 7599-7605. [CrossRef]

44. Friščić, T. Supramolecular concepts and new techniques in mechanochemistry: Cocrystals, cages, rotaxanes, open metal-organic frameworks. Chem. Soc. Rev. 2012, 41, 3493-3510. [CrossRef] [PubMed]

45. Do, J.-L.; Friščić, T. Mechanochemistry: A Force of Synthesis. ACS Central Sci. 2017, 3, 13-19. [CrossRef] [PubMed]

46. Quaresma, S.; André, V.; Fernandes, A.; Duarte, M.T. Mechanochemistry - A green synthetic methodology leading to metallodrugs, metallopharmaceuticals and bio-inspired metal-organic frameworks. Inorganica Chim. Acta 2017, 455, 309-318. [CrossRef]

47. Altaf, M.; Miller, C.H.; Bellows, D.S.; O'Toole, R. Evaluation of the Mycobacterium smegmatis and BCG models for the discovery of Mycobacterium tuberculosis inhibitors. Tuberc. 2010, 90, 333-337. [CrossRef]

48. Etienne, G.; Laval, F.; Villeneuve, C.; Dinadayala, P.; Abouwarda, A.; Zerbib, D.; Galamba, A.; Daffé, M. The cell envelope structure and properties of Mycobacterium smegmatis mc2155: Is there a clue for the unique transformability of the strain? Microbiol. 2005, 151, 2075-2086. [CrossRef] [PubMed]

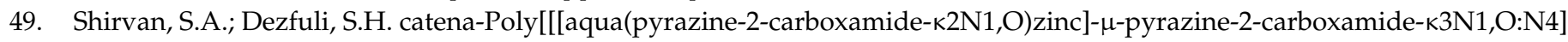
dinitrate]. Acta Crystallogr. Sect. E Struct. Rep. Online 2012, 68, m627-m628. [CrossRef]

50. Yamada, H.; Yamaguchi, M.; Igarashi, Y.; Chikamatsu, K.; Aono, A.; Murase, Y.; Morishige, Y.; Takaki, A.; Chibana, H.; Mitarai, S. Mycolicibacterium smegmatis, Basonym Mycobacterium smegmatis, Expresses Morphological Phenotypes Much More Similar to Escherichia coli Than Mycobacterium tuberculosis in Quantitative Structome Analysis and CryoTEM Examination. Front. Microbiol. 2018, 9, 1992. [CrossRef] [PubMed]

51. Fu, L.M.; Fu-Liu, C.S. Is Mycobacterium tuberculosis a closer relative to Gram-positive or Gram-negative bacterial pathogens? Tuberculosis 2002, 82, 85-90. [CrossRef]

52. Hett, E.C.; Rubin, E.J. Bacterial Growth and Cell Division: A Mycobacterial Perspective. Microbiol. Mol. Biol. Rev. 2008, 72, 126-156. [CrossRef] [PubMed]

53. Macrae, C.F.; Bruno, I.J.; Chisholm, J.A.; Edgington, P.R.; McCabe, P.; Pidcock, E.; Rodriguez-Monge, L.; Taylor, R.J.; Van De Streek, J.; Wood, P.A. Mercury CSD 2.0- new features for the visualization and investigation of crystal structures. J. Appl. Crystallogr. 2008, 41, 466-470. [CrossRef]

54. Bruker AXS:SAINT+, release 6.22; Bruker Analytical Systems: Madison, WI, USA, 2005.

55. Bruker AXS:SADABS; Bruker Analytical Systems: Madison, WI, USA, 2005.

56. Sheldrick, G.M. SHELXT- Integrated space-group and crystal-structure determination. Acta Cryst. 2015, 71, 3-8. [CrossRef] [PubMed]

57. Sheldrick, G.M. Crystal structure refinement with SHELXL. Acta Cryst. 2015, 71, 3-8. [CrossRef]

58. Farrugia, L.J. WinGX suite for small-molecule single-crystal crystallography. J. Appl. Crystallogr. 1999, 32, 837-838.

59. Spek, A.L. Single-crystal structure validation with the programPLATON. J. Appl. Crystallogr. 2003, 36, 7-13. [CrossRef]

60. Siopa, F.; Figueiredo, T.; Frade, R.F.M.; Neto, I.; Meirinhos, A.; Reis, C.P.; Sobral, R.G.; Afonso, C.A.M.; Rijo, P. Choline-Based Ionic Liquids: Improvement of Antimicrobial Activity. ChemistrySelect 2016, 1, 5909-5916. [CrossRef]

61. CLSI. Methods for Dilution Antimicrobial Susceptibility Tests for Bacteria that Grow Aerobically, 11th ed.; CLSI: Wayne, PA, USA, 2018. 